\section{A) Check for updates}

Cite this: Dalton Trans., 2021, 50 , 4805

Received 25th January 2021, Accepted 16th March 2021

DOI: $10.1039 / \mathrm{d} 1 \mathrm{dt} 00252 \mathrm{j}$

rsc.li/dalton

\title{
Ring-opening polymerisation of $\mathrm{L}-$ and rac-lactide using group 4 permethylpentalene aryloxides and alkoxides $\uparrow$
}

\author{
Zoë R. Turner, (D) Jessica V. Lamb, Thomas P. Robinson, Dipa Mandal, \\ Jean-Charles Buffet (iD) and Dermot O'Hare (D) *
}

\begin{abstract}
A new family of group 4 permethylpentalene $\left(\mathrm{C}_{8} \mathrm{Me}_{6}{ }^{2-} ; \mathrm{Pn}\right)$ aryloxide and alkoxide complexes have been synthesised and fully characterised by multinuclear NMR spectroscopy and single-crystal X-ray diffraction; $\left(\eta^{8}-\mathrm{C}_{8} \mathrm{Me}_{6}\right) \mathrm{Zr}(\mathrm{OR})_{2}\left(\mathrm{R}={ }^{t} \mathrm{Bu}(\mathbf{1}), 2,6-\mathrm{Me}-\mathrm{C}_{6} \mathrm{H}_{3}(2), 2,6-{ }^{i} \mathrm{Pr}-\mathrm{C}_{6} \mathrm{H}_{3}(\mathbf{3})\right.$ and 4-OMe- $\left.\mathrm{C}_{6} \mathrm{H}_{4}(4)\right),\left(\eta^{8}-\mathrm{C}_{8} \mathrm{Me}_{6}\right) \mathrm{Zr}(\mathrm{OR})$

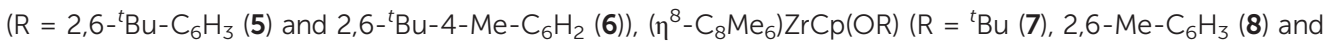
2,6- $\left.{ }^{i} \mathrm{Pr}-\mathrm{C}_{6} \mathrm{H}_{3}(\mathbf{9})\right),\left(\eta^{8}-\mathrm{C}_{8} \mathrm{Me}_{6}\right) \mathrm{TiCp}\left(\mathrm{O}-2,6-\mathrm{Me}-\mathrm{C}_{6} \mathrm{H}_{3}\right)(10)$ and $\left(\eta^{8}-\mathrm{C}_{8} \mathrm{Me}_{6}\right) \mathrm{ZrCp}^{\mathrm{Me}}(\mathrm{OR})\left(\mathrm{R}=2,6-\mathrm{Me}^{-\mathrm{C}_{6} \mathrm{H}_{3}}\right.$ (11), 2,6- ${ }^{i} \mathrm{Pr}-\mathrm{C}_{6} \mathrm{H}_{3}(\mathbf{1 2})$ and $2,4-{ }^{t} \mathrm{Bu}-\mathrm{C}_{6} \mathrm{H}_{3}$ (13)). 2, 3, 6, 7, 9, 10 and 12 were studied as initiators for the ringopening polymerisation (ROP) of L-lactide, and 2, 3, 6, 7 and 10 were studied as initiators for the ROP of rac-lactide. 3 was found to be the most active initiator for the ROP of L-lactide $\left(k_{\mathrm{obs}}=0.35 \mathrm{~h}^{-1}\right)$ and $\mathbf{2}$ for the ROP of rac-lactide $\left(k_{\mathrm{obs}}=0.21 \mathrm{~h}^{-1}\right)$. These initiators produced isotactic PLA for the ROP of L-lactide and moderately heterotactic enriched (maximum $P_{r}$ of 0.69 ) or atactic PLA for the ROP of rac-lactide with polymer chains consisting of polylactic acid repeat units with - OR and $-\mathrm{OH}$ end groups.
\end{abstract}

\section{Introduction}

Polyolefins have diverse uses, including packaging, agriculture and medical applications. ${ }^{1}$ However, the resistance of polyolefins to chemical, physical and biological degradation has become a serious environmental concern. ${ }^{2}$ Therefore, there is a global necessity for biodegradable and biocompatible polymers derived from renewable feedstocks that can be broken down into smaller molecules (such as $\mathrm{CO}_{2}, \mathrm{CH}_{4}$ and $\mathrm{H}_{2} \mathrm{O}$ ) naturally by microorganisms. ${ }^{1,3-7}$ Polylactides (PLAs) produced from the ring-opening polymerisation (ROP) of lactide are one the most versatile materials among biodegradable polymers due to their inherent biodegradability, biocompatibility, high mechanical strength, low toxicity and easy availability from renewable sources..$^{3-5,8,9}$ The versatile properties of PLAs enables their use in a wide range of applications, from biomedical and pharmaceutical materials for tissue engineering and wound dressings to biodegradable materials for bags and

\footnotetext{
Chemistry Research Laboratory, Department of Chemistry, University of Oxford, 12, Mansfield Road, OX1 3TA Oxford, UK. E-mail: dermot.ohare@chem.ox.ac.uk; Tel: +44 (0)1865 272686

$\dagger$ Electronic supplementary information (ESI) available: General details, NMR spectroscopy, crystallographic data and definitions of structural parameters, and additional polymerisation data and characterisation information. CCDC 2057993-2057999. For ESI and crystallographic data in CIF or other electronic format see DOI: 10.1039/d1dt00252j
}

cutlery. ${ }^{3,10-12}$ The stereochemistry of the lactide monomer units leads to PLA chains with diverse stereochemical arrangements. This results in variations in the mechanical, physical and thermal degradation properties of the polymers, which play a crucial role in determining the potential applications. Stereospecific, single-site catalysts with the ability to control polymer architectures are therefore highly desired.

A range of metal complexes and ligand frameworks have been studied as single-site initiators ${ }^{6,13,14-17}$ for the stereoselective ROP of lactide (indium, ${ }^{18-21}$ scandium and yttrium, ${ }^{22-27}$ lanthanum ${ }^{28,29}$ samarium, ${ }^{29}$ and iron $^{30}$ ). For the polymerisation of rac-lactide, high levels of isotactic stereocontrol were observed when using indium initiators $\left(P_{\mathrm{m}}\right.$ up to 0.87$)$, while highly heterotactic PLA was obtained for yttrium initiators $\left(P_{\mathrm{r}}>0.87\right) \cdot{ }^{20,23}$ Spassky and co-workers first reported chiral salen complexes affording isotactic PLA from rac-lactide. ${ }^{31,32}$ Aluminium complexes bearing tetradentate $N, N^{\prime}$-disubstituted bis(amino-phenoxide) ${ }^{33-37}$ also show high degrees of stereocontrol for the polymerisation of rac-lactide, with polymer tacticity largely dependent on the ligand substituents; isotactic PLAs are produced with unsubstituted phenoxide groups ( $P_{\mathrm{m}}$ up to 0.98 ), while highly heterotactic PLAs are obtained with 3,5-substituted phenoxide groups $\left(P_{\mathrm{r}}\right.$ up to 0.96$){ }^{38} \beta$-Diiminate zinc complexes have also been shown to afford highly heterotactic PLA from the ROP of $r a c$-lactide $\left(P_{\mathrm{r}}\right.$ up to 0.94$){ }^{39}$

Group 4 complexes are far less studied as initiators for the ROP of lactide. However, zirconium alkoxide compounds 
bearing a tridentate $\mathrm{N}$-heterocyclic carbene-linked bis(phenolate) ligand have been reported to show controlled and highly stereoselective ROP of rac-lactide to yield heterotactic PLA under mild conditions $\left(P_{\mathrm{r}}>0.95\right) .{ }^{40}$ Zirconium and hafnium amine tris(phenolate) alkoxides also show high activity and stereocontrol for the ROP of rac-lactide with heterotactic PLA produced under solvent-free conditions $\left(P_{\mathrm{r}}>0.90\right) .{ }^{41}$ O'Hare and co-workers have also reported families of well-defined zirconium and hafnium biscyclopentadienyl, bisindenyl and unsymmetrical permethylindenyl complexes that were active for the ROP of $\mathrm{L}^{-}, \mathrm{D}^{-}$and rac-lactide with varying degrees of stereocontrol achieved. ${ }^{42,43}$ In addition, we recently reported a new family of chiral group 4 alkoxide and aryloxide half-sandwich $\eta^{5}$-complexes of a chiral cyclopentadienyl-derived (hydro)permethylpentalenyl ligand $\left\{\left(\mathrm{C}_{8} \mathrm{Me}_{6} \mathrm{H}\right) \mathrm{ML}_{3} ; \mathrm{Pn}^{*}(\mathrm{H}) \mathrm{ML}_{3}\right\}$ as very active initiators for the ROP of $\mathrm{L}^{-}$and rac-lactide. ${ }^{56}$

Herein, following on from our work on $\mathrm{Pn}^{*} \mathrm{MX}_{2},{ }^{44,45}$ we report the development of a new family of group $4 \eta^{8}$-permethylpentalenyl complexes of the type $\left\{\left(\eta^{8}-\mathrm{C}_{8} \mathrm{Me}_{6}\right) \mathrm{ML}_{2}\right.$; $\left.\mathrm{Pn}^{*} \mathrm{ML}_{2}\right\}$ (Chart 2) as initiators for the ROP of $\mathrm{L}^{-}$and raclactide. By targeting $\mathrm{Pn}^{*} \mathrm{ML}_{2}$ complexes the stereoelectronic properties of the ancillary ligands and initiation groups can be varied to influence polymerisation activity and stereocontrol.

\section{Results and discussion}

\section{Synthesis and characterisation of $\mathrm{Pn}^{*} \mathrm{Zr}(\mathrm{OR})_{2}$ and $\mathrm{Pn}{ }^{*} \mathrm{ZrCl}(\mathrm{OR})$}

The reaction of one equivalent of previously synthesised $\left[\mathrm{Pn}^{*} \mathrm{ZrCl}_{2}\right]_{2} \cdot \mathrm{LiCl}(\mathrm{thf})_{x}{ }^{46}$ with four equivalents $\mathrm{KOR}\left(\mathrm{R}={ }^{t} \mathrm{Bu}\right.$, 2,6-Me- $\mathrm{C}_{6} \mathrm{H}_{3}$ and $2,6-{ }^{i} \mathrm{Pr}-\mathrm{C}_{6} \mathrm{H}_{3}$ ) afforded two equivalents of the bis(alkoxide) complexes $\mathrm{Pn}^{*} \mathrm{Zr}\left(\mathrm{O}^{t} \mathrm{Bu}\right)_{2} \quad$ (1), $\quad \mathrm{Pn}{ }^{*} \mathrm{Zr}(\mathrm{O}-2,6-\mathrm{Me}-$ $\left.\mathrm{C}_{6} \mathrm{H}_{3}\right)_{2}$ (2) and $\mathrm{Pn} * \mathrm{Zr}\left(\mathrm{O}-2,6-{ }^{i}{ }^{\mathrm{Pr}}-\mathrm{C}_{6} \mathrm{H}_{3}\right)_{2}$ (3) (Charts 1 and 2). 1 was synthesised in a Young's tap NMR spectroscopy tube as preparative-scale synthesis was hindered by its instability (formation of intractable mixture of species). Complexes 2 and 3 were synthesised on a preparative scale and isolated as yellow solids in 78 and $79 \%$ yields respectively. The mono(aryloxide) complex $\mathrm{Pn}^{*} \mathrm{ZrCl}\left(\mathrm{O}-2,6-\mathrm{Me}-\mathrm{C}_{6} \mathrm{H}_{3}\right)$ can also be formed by the addition of sub-stoichiometric amounts of KO-2,6-Me- $\mathrm{C}_{6} \mathrm{H}_{3}$ to $\left[\mathrm{Pn} * \mathrm{ZrCl}_{2}\right]_{2} \cdot \operatorname{LiCl}(\text { thf })_{x}$. The ${ }^{1} \mathrm{H}$ NMR spectra of $\mathbf{1}, 2$ and 3 show two singlets with integration 6 and 12 between 1.86 and $2.13 \mathrm{ppm}$, which are diagnostic of the wing-tip and non-wingtip methyl groups of the $\mathrm{Pn}^{*}$ ligand respectively and are consistent with molecules of $C_{2 \mathrm{v}}$ symmetry (Fig. S1, S3 and S4 $\dagger$ ).

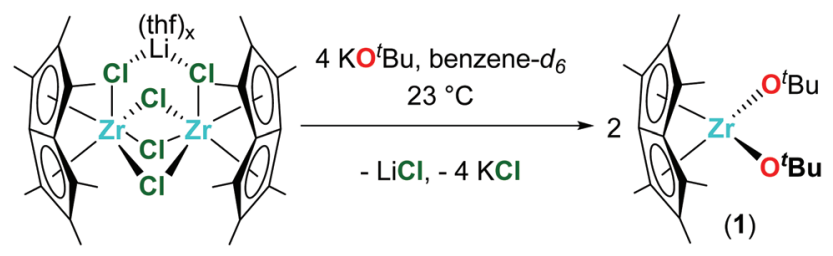

Chart 1 Synthesis of $\mathrm{Pn}{ }^{\star} \mathrm{Zr}\left(\mathrm{O}^{t} \mathrm{Bu}\right)_{2}$ (1).

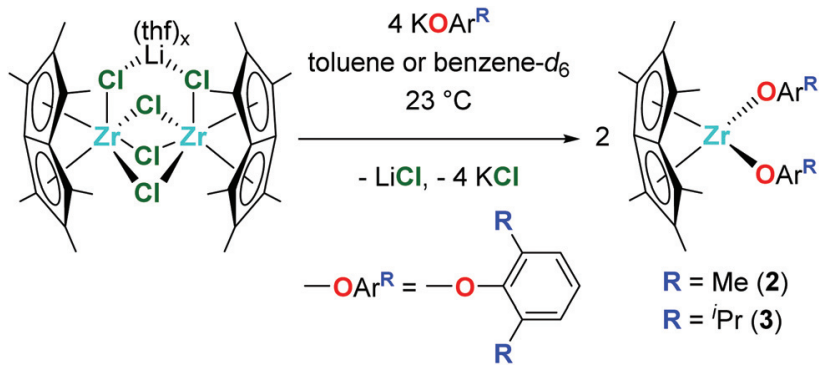

Chart 2 Synthesis of $\mathrm{Pn}{ }^{*} \mathrm{Zr}\left(\mathrm{O}-2,6-\mathrm{Me}-\mathrm{C}_{6} \mathrm{H}_{3}\right)_{2}$ (2) and $\mathrm{Pn}{ }^{*} \mathrm{Zr}\left(\mathrm{O}-2,6-{ }^{i} \mathrm{Pr}-\right.$ $\left.\mathrm{C}_{6} \mathrm{H}_{3}\right)_{2}(3)$.

For 1, a singlet at $1.24 \mathrm{ppm}$ represents the protons of the $t$-butyl groups, while for 2 and 3, a doublet at approximately $7.00 \mathrm{ppm}$ and a triplet at approximately $6.85 \mathrm{ppm}$ define the aromatic protons of the aryloxide group. The methyl resonances of the aryloxide group of 2 are observed as a singlet at $2.16 \mathrm{ppm}$, while for 3 , a doublet at $1.24 \mathrm{ppm}$ and a septet at $3.20 \mathrm{ppm}$ represent the isopropyl methyl groups and methine proton respectively.

Crystals of 2 and 3 suitable for single crystal X-ray diffraction studies were grown from hexane solutions at $-30{ }^{\circ} \mathrm{C}$. The solid-state molecular structures are depicted in Fig. 1, with selected bond lengths and angles presented in Table 1. Compound 2 suffers from disorder which have been fixed using SADI. Hence, caution should be applied when discussing the metrical parameters. Nevertheless, compounds 2 and 3 are isostructural in the solid state and adopt distorted tetrahedral geometries, exemplified by the $\mathrm{O}(1)-\mathrm{Zr}(1)-\mathrm{O}(2)$ angles of 98.6(4) and $101.18(5)^{\circ}$ respectively.

Both complexes show similar $\mathrm{Zr}-\mathrm{O}$ distances; 2.015(6) and 1.963(3) $\AA$ for 2 and 1.9896(11) and 1.9901(11) A for 3, which are slightly longer than the Ti-O distances of analogous $\mathrm{Pn}^{*} \mathrm{Ti}$ $\left(\mathrm{O}-2,6-\mathrm{Me}-\mathrm{C}_{6} \mathrm{H}_{3}\right)_{2}$ (1.8712 and $\left.1.8890 \AA\right),{ }^{47}$ likely due to the larger size of zirconium compared to titanium. The $\mathrm{Zr}-\mathrm{O}$ bond lengths of 2 and 3 are comparable to average values reported for other zirconium aryloxide complexes: 1.9628(1), 1.97(1), 1.9873(1) and $1.997 \AA$ for ${ }^{\mathrm{Me} 2} \mathrm{SB}\left(\mathrm{Cp}, \mathrm{I}^{*}\right) \mathrm{ZrCl}\left(\mathrm{O}-2,6-\mathrm{Me}-\mathrm{C}_{6} \mathrm{H}_{3}\right)$, $\mathrm{Cp}_{2} \mathrm{ZrCl}\left(\mathrm{O}-2,6-{ }^{i} \mathrm{Pr}-\mathrm{C}_{6} \mathrm{H}_{3}\right),{ }^{\mathrm{Me} 2} \mathrm{SB}\left(\mathrm{Cp}, \mathrm{I}^{*}\right) \mathrm{ZrCl}\left(\mathrm{O}-2,6-{ }^{i} \mathrm{Pr}-\mathrm{C}_{6} \mathrm{H}_{3}\right)$ and $\mathrm{Cp}_{2} \mathrm{Zr}\left(\mathrm{O}-2,6-\mathrm{Me}-\mathrm{C}_{6} \mathrm{H}_{3}\right)_{2}$ respectively. ${ }^{43,48-50}$ The $\mathrm{Zr}-\mathrm{O}$ bond lengths for 2 and 3 are significantly shorter than the sum of the covalent radii of zirconium and oxygen (1.75 and $0.66 \AA$ respectively), indicating that there is a partial ionic character to the $\mathrm{Zr}-\mathrm{O}$ bond. ${ }^{51}$ The two $\mathrm{Zr}-\mathrm{O}-\mathrm{C}$ angles of 2 are very similar, however the aryloxide ligands point in different directions; $\mathrm{Zr}(1)-\mathrm{O}(1)-\mathrm{C}(15)$ points towards the $\mathrm{Pn}^{*}$ ligand with an angle of $164.2(9)^{\circ}$, while $\operatorname{Zr}(1)-\mathrm{O}(1)-\mathrm{C}(22)$ points away from the $\mathrm{Pn}^{*}$ ligand with an angle of $164.2(7)^{\circ}$. This is in agreement with $\mathrm{Pn}^{*} \mathrm{Ti}\left(\mathrm{O}-2,6-\mathrm{Me}-\mathrm{C}_{6} \mathrm{H}_{3}\right)_{2}$, where one aryloxide group points towards the $\mathrm{Pn}^{*}$ ligand with $\mathrm{Ti}-\mathrm{O}-\mathrm{C}$ of $159.15^{\circ}$ and the other aryloxide group points away from the $\mathrm{Pn}^{*}$ ligand with $\mathrm{Ti}-\mathrm{C}-\mathrm{O}$ of $143.87^{\circ} .{ }^{47}$ For 3 , the $\mathrm{Zr}-\mathrm{O}-\mathrm{C}$ angles of the two aryloxide ligands are slightly different (165.20(11) and $\left.158.69(10)^{\circ}\right)$; however, both aryloxide groups point towards the $\mathrm{Pn}^{*}$ ligand. Both 2 and 3 have similar $\mathrm{Zr}-\mathrm{Pn}^{*}{ }_{\text {cent }}$ distances $(2.089$ and 

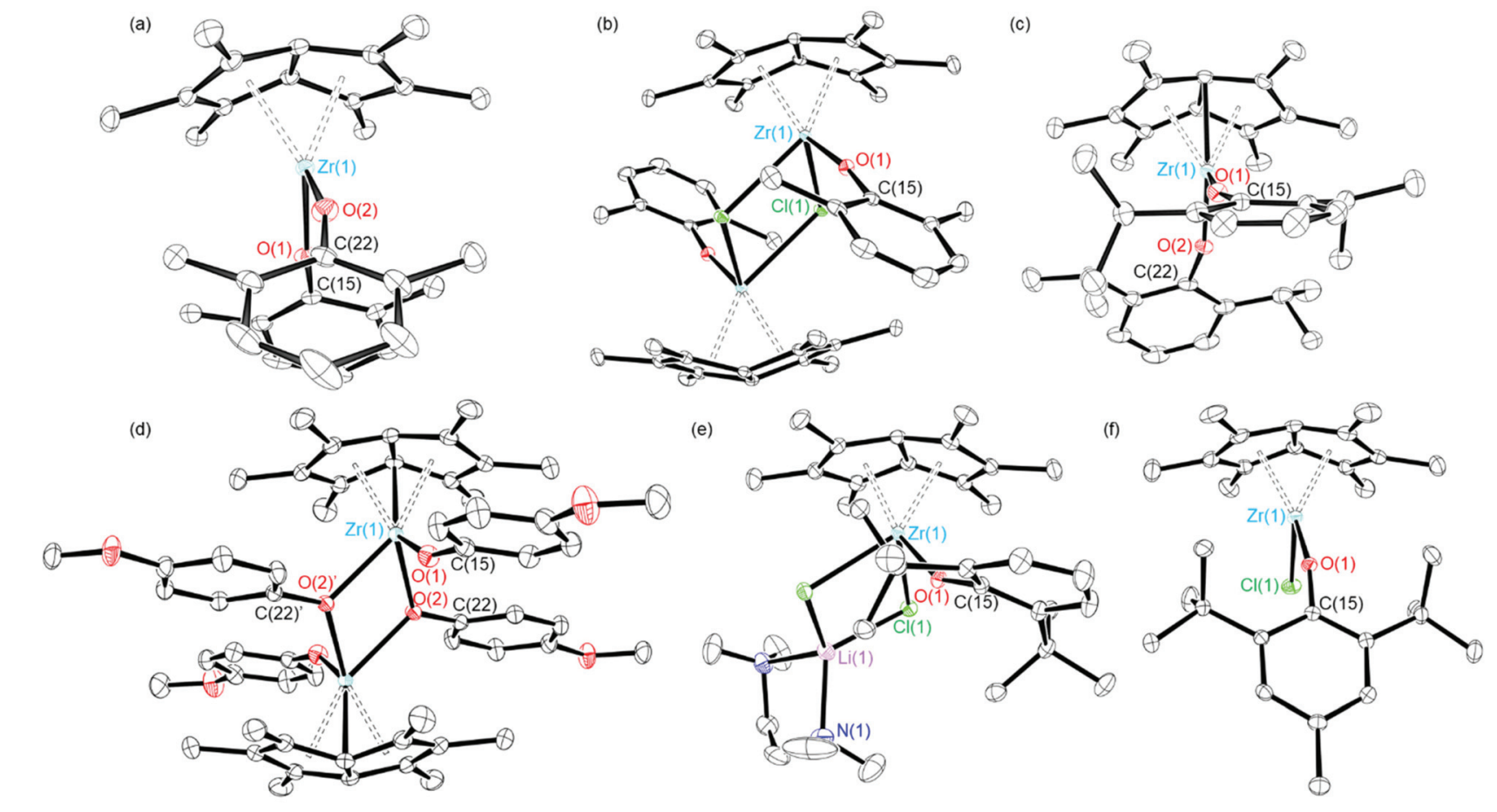

Fig. 1 Solid-state molecular structures of (a) $\mathrm{Pn} * \mathrm{Zr}\left(\mathrm{O}-2,6-\mathrm{Me}-\mathrm{C}_{6} \mathrm{H}_{3}\right)_{2}$ (2), (b) $\mathrm{Pn} * \mathrm{ZrCl}\left(\mathrm{O}-2,6-\mathrm{Me}-\mathrm{C}_{6} \mathrm{H}_{3}\right)_{2},(\mathrm{c}) \mathrm{Pn} * \mathrm{Zr}\left(\mathrm{O}-2,6-{ }^{i} \mathrm{Pr}-\mathrm{C}_{6} \mathrm{H}_{3}\right)_{2}(3),(\mathrm{d})[\mathrm{Pn} * \mathrm{Zr}$ $\left.\left(\mathrm{O}-4-\mathrm{OMe}-\mathrm{C}_{6} \mathrm{H}_{4}\right)_{2}\right]_{2}\left(4^{\prime}\right)$, (e) $\mathrm{Pn} * \mathrm{Zr}\left(\mathrm{O}-2,6-{ }^{t} \mathrm{Bu}-\mathrm{C}_{6} \mathrm{H}_{3}\right)_{2} \mathrm{Cl} \cdot \mathrm{tmeda}$ and (f) $\mathrm{Pn} * \mathrm{ZrCl}\left(\mathrm{O}-2,6-{ }^{t} \mathrm{Bu}-4-\mathrm{Me}-\mathrm{C}_{6} \mathrm{H}_{2}\right)$ (6). $\mathrm{H}$ atoms omitted for clarity. Ellipsoids given at $30 \%$ probability.

Table 1 Selected bond lengths (Å) and angles ( $\left.{ }^{\circ}\right)$ for $\mathrm{Pn} * \mathrm{Zr}\left(\mathrm{O}-2,6-\mathrm{Me}-\mathrm{C}_{6} \mathrm{H}_{3}\right)_{2}(2), \mathrm{Pn} * \mathrm{ZrCl}\left(\mathrm{O}-2,6-\mathrm{Me}-\mathrm{C}_{6} \mathrm{H}_{3}\right)_{2}, \mathrm{Pn} * \mathrm{Zr}\left(\mathrm{O}-2,6-{ }^{i} \mathrm{Pr}-\mathrm{C}_{6} \mathrm{H}_{3}\right)_{2}(3),[\mathrm{Pn} * \mathrm{Zr}$ $\left.\left(\mathrm{O}-4-\mathrm{OMe}-\mathrm{C}_{6} \mathrm{H}_{4}\right)_{2}\right]_{2}\left(4^{\prime}\right), \mathrm{Pn}{ }^{*} \mathrm{ZrCl}\left(\mathrm{O}-2,6-{ }^{t} \mathrm{Bu}-\mathrm{C}_{6} \mathrm{H}_{3}\right)_{2} \cdot \mathrm{LiCl}(\mathrm{tmeda}), \mathrm{Pn}{ }^{\star} \mathrm{ZrCl}\left(\mathrm{O}-2,6-{ }^{t} \mathrm{Bu}-4-\mathrm{Me}-\mathrm{C}_{6} \mathrm{H}_{2}\right)(6)$ and $\mathrm{Pn}{ }^{*} \mathrm{ZrCp}{ }^{\mathrm{Me}}\left(\mathrm{O}-2,6-{ }^{i} \mathrm{Pr}-\mathrm{C}_{6} \mathrm{H}_{3}\right)(12)$

\begin{tabular}{|c|c|c|c|c|c|c|}
\hline Complex & $\begin{array}{l}\mathrm{Zr}(1)-\mathrm{O}(1) \\
(\AA)\end{array}$ & $\begin{array}{l}\mathrm{Zr}(1)-\mathrm{O}(2) \\
(\AA)\end{array}$ & $\begin{array}{l}\mathrm{Zr}(1)-\mathrm{Cl}(1) \\
(\AA)\end{array}$ & $\operatorname{Zr}(1)-\mathrm{Pn}^{*}$ cent $(\AA)$ & $\begin{array}{l}\operatorname{Zr}(1)-O(1)-C(15) \\
\left({ }^{\circ}\right)\end{array}$ & $\begin{array}{l}\mathrm{Zr}(1)-\mathrm{O}(2)-\mathrm{C}(22) \\
\left({ }^{\circ}\right)\end{array}$ \\
\hline $\mathrm{Pn}{ }^{*} \mathrm{Zr}\left(\mathrm{O}-2,6-\mathrm{Me}-\mathrm{C}_{6} \mathrm{H}_{3}\right)_{2}(2)$ & $2.015(6)$ & $1.963(3)$ & - & $2.090,2.087$ & 164.2(9) & 164.2(7) \\
\hline $\mathrm{Pn}^{*} \mathrm{ZrCl}\left(\mathrm{O}-2,6-\mathrm{Me}-\mathrm{C}_{6} \mathrm{H}_{3}\right)^{a}$ & $1.9844(14)$ & - & $2.5767(5)$ & $2.1116(1), 2.1161(6)$ & $174.38(6)$ & - \\
\hline$\left[\mathrm{Pn} * \mathrm{Zr}\left(\mathrm{O}-4-\mathrm{OMe}-\mathrm{C}_{6} \mathrm{H}_{4}\right)_{2}\right]_{2}\left(4^{\prime}\right)$ & $2.0190(13)$ & $2.2176(6)^{b}$ & & $2.1423(1), 2.1557(1)$ & $154.07(12)$ & $124.43(4)^{c}$ \\
\hline $\begin{array}{l}\mathrm{Pn}^{*} \mathrm{ZrCl}\left(\mathrm{O}-2,6-{ }^{t} \mathrm{Bu}-\mathrm{C}_{6} \mathrm{H}_{2}\right) \cdot \mathrm{LiCl} \\
\text { (tmeda) }\end{array}$ & $2.0399(9)$ & - & $2.5635(3)$ & $2.1412(8), 2.1479(7)$ & $152.49(9)$ & - \\
\hline
\end{tabular}

${ }^{a}$ Solid-state parameters are given as average of the two independent molecules in the asymmetric unit. ${ }^{b}$ Average of $\mathrm{Zr}(1)-\mathrm{O}(2)$ and $\mathrm{Zr}(1)-\mathrm{O}(2)$. ${ }^{c}$ Average of $\mathrm{Zr}(1)-\mathrm{O}(2)-\mathrm{C}(22)$ and $\mathrm{Zr}(1)-\mathrm{O}(2)^{\prime}-\mathrm{C}(22)$.

$2.096 \AA$ respectively) and similar $\mathrm{Pn}^{*}$ fold angles, defined as the angle by which the $\mathrm{Pn}^{*}$ ligand deviates from planarity, ${ }^{52}$ (32.28 and $32.53^{\circ}$ respectively), which are similar to those reported for $\mathrm{Pn}{ }^{*} \mathrm{Ti}\left(\mathrm{O}-2,6-\mathrm{Me}-\mathrm{C}_{6} \mathrm{H}_{3}\right)_{2}$; average $\mathrm{Ti}-\mathrm{Pn}^{*}$ cent of $1.9492 \AA$ and fold angle of $34.46^{\circ} .{ }^{47}$

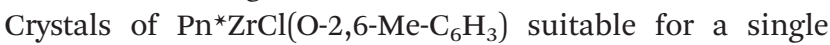
crystal X-ray diffraction study were obtained from benzene- $d_{6}$ at $25{ }^{\circ} \mathrm{C}$ (Fig. 1 and Table 1 ). The relatively low steric demands of the aryloxide ligand allow dimerisation to occur in the solid-state. In addition, the solid-state structure shows two molecules in the asymmetric unit, akin to $\mathrm{Pn}^{*} \mathrm{TiCl}(\mathrm{O}-2,6-\mathrm{Me}-$ $\left.\mathrm{C}_{6} \mathrm{H}_{3}\right) .{ }^{47}$ The $\mathrm{Zr}-\mathrm{O}$ bond length of $\mathrm{Pn}{ }^{*} \mathrm{ZrCl}\left(\mathrm{O}-2,6-\mathrm{Me}-\mathrm{C}_{6} \mathrm{H}_{3}\right)$ is similar to the average $\mathrm{Zr}-\mathrm{O}$ distance of bis(aryloxide) 2 (1.9844(14) and 1.989(5) Å respectively), however is longer than the Ti-O distance of $\mathrm{Pn}^{*} \mathrm{TiCl}\left(\mathrm{O}-2,6-\mathrm{Me}-\mathrm{C}_{6} \mathrm{H}_{3}\right)(1.838(2) \AA) .{ }^{47}$ The $\mathrm{Zr}-\mathrm{O}-\mathrm{C}$ angle is larger than for 2 and 3 (170.87(13), 164.27 and $158.69(10)^{\circ}$ respectively), likely due to the increased steric bulk caused by dimerisation, with the aryloxide group pointing away from the $\mathrm{Pn}^{*}$ ligand. The near-linear nature of the $\mathrm{Zr}-\mathrm{O}-$ $\mathrm{C}$ angle of $\mathrm{Pn}{ }^{*} \mathrm{ZrCl}\left(\mathrm{O}-2,6-\mathrm{Me}-\mathrm{C}_{6} \mathrm{H}_{3}\right)$ suggests some $\pi$-orbital interaction between $\mathrm{Zr}$ and $\mathrm{O}$, and is in good agreement with the values reported for mono(aryloxides) $\mathrm{Cp}_{2} \mathrm{ZrCl}(\mathrm{O}-2,6-\mathrm{Me}-$ $\left.\mathrm{C}_{6} \mathrm{H}_{3}\right)$ and $\mathrm{Cp}_{2} \mathrm{ZrCl}\left(\mathrm{O}-2,6{ }^{\mathrm{i}}{ }^{\mathrm{Pr}}-\mathrm{C}_{6} \mathrm{H}_{3}\right) \quad\left(171.6\right.$ and $172(1)^{\circ}$ respectively). ${ }^{42,48}$ 
Dimeric $\left[\mathrm{Pn}{ }^{*} \mathrm{Zr}\left(\mathrm{O}-4-\mathrm{OMe}-\mathrm{C}_{6} \mathrm{H}_{4}\right)_{2}\right]_{2}\left(\mathbf{4}^{\prime}\right)$ was synthesised by the reaction of one equivalent $\left[\mathrm{Pn}^{*} \mathrm{ZrCl}_{2}\right]_{2} \cdot \mathrm{LiCl} \cdot(\mathrm{thf})_{2}$ with four equivalents KO-4-OMe- $\mathrm{C}_{6} \mathrm{H}_{4}$ (Scheme 1). Dissolution of $\left[\mathrm{Pn}^{*} \mathrm{Zr}\right.$ (O-4-OMe- $\left.\left.\mathrm{C}_{6} \mathrm{H}_{4}\right)_{2}\right]_{2}\left(4^{\prime}\right)$ followed by heating to $65{ }^{\circ} \mathrm{C}$ resulted in dissociation of the dimer to afford $\mathrm{Pn}{ }^{*} \mathrm{Zr}\left(\mathrm{O}-4-\mathrm{OMe}-\mathrm{C}_{6} \mathrm{H}_{4}\right)_{2}$ (4). The ${ }^{1} \mathrm{H}$ NMR spectrum of $\mathbf{4}$ shows the diagnostic wing-tip and non-wing tip $\mathrm{Pn}^{*}$ methyl group resonances at 2.01 and $1.99 \mathrm{ppm}$ respectively (Fig. S6†). A singlet at $3.63 \mathrm{ppm}$ corresponds to the methyl group of the aryloxide ligand, while doublets at 6.64 and $6.50 \mathrm{ppm}$ represent the aromatic protons. Crystals of $\left[\mathrm{Pn}{ }^{*} \mathrm{Zr}\left(\mathrm{O}-4-\mathrm{OMe}-\mathrm{C}_{6} \mathrm{H}_{4}\right)_{2}\right]_{2} \quad\left(\mathbf{4}^{\prime}\right)$ suitable for a single crystal X-ray diffraction study were obtained from benzene- $d_{6}$ at $25{ }^{\circ} \mathrm{C}$ (Fig. 1 and Table 1). The structure contains two bridging aryloxide ligands and two terminal aryloxide ligands, where the $\mathrm{Zr}-\mathrm{O}$ bridging bond lengths (2.2665(1) and 2.1688(11) $\AA)$ are longer than the $\mathrm{Zr}-\mathrm{O}$ terminal bond lengths $(2.0190(13)$ $\AA)$. The $\mathrm{Zr}-\mathrm{O}-\mathrm{C}$ angles of the two bridging aryloxide ligands are significantly smaller than the $\mathrm{Zr}-\mathrm{O}-\mathrm{C}$ angle of the terminal aryloxide ligands (126.80(9), 122.05(9) and 154.07(12) ${ }^{\circ}$ respectively), likely due to the steric constraints of dimerisation. By increasing the steric bulk in the 2,6-positions of the phenyl ring, mono-substituted $\mathrm{Pn} * \mathrm{ZrCl}\left(\mathrm{O}-2,6-{ }^{t} \mathrm{Bu}^{-} \mathrm{C}_{6} \mathrm{H}_{3}\right)$ (5) and $\mathrm{Pn}^{*} \mathrm{ZrCl}\left(\mathrm{O}-2,6-{ }^{t} \mathrm{Bu}-4-\mathrm{Me}-\mathrm{C}_{6} \mathrm{H}_{2}\right)(\mathbf{6})$ were obtained from the reaction of one equivalent $\left[\mathrm{Pn}^{*} \mathrm{ZrCl}_{2}\right]_{2} \cdot \mathrm{LiCl}(\mathrm{thf})_{x}$ (TMEDA is present in 5 due to its presence in the starting material) with four equivalents $\operatorname{KOAr}\left(\mathrm{R}=2,6-{ }^{t} \mathrm{Bu}-\mathrm{C}_{6} \mathrm{H}_{3}\right.$ and $2,6-{ }^{t} \mathrm{Bu}-4-\mathrm{Me}-$ $\mathrm{C}_{6} \mathrm{H}_{2}$ ) at 25 and $70{ }^{\circ} \mathrm{C}$, respectively, in quantitative yield (Chart 3). 6 was also isolated on a preparative scale in $83 \%$ yield.

The ${ }^{1} \mathrm{H}$ NMR spectrum of 6 contains two diagnostic singlets in an $18: 3$ ratio at 1.44 and $2.34 \mathrm{ppm}$ corresponding to the tert-butyl and methyl groups of the aryloxide ligand (Fig. S8 †). The $\mathrm{Pn}^{*}$ methyl resonances appear as two singlets at 2.06 and $1.84 \mathrm{ppm}$ in a 12:6 ratio (two resonances juxtaposing). At temperatures below $213 \mathrm{~K}$ these resonances split into three singlets in a 6:6:6 ratio (Fig. S10†), as would typically be expected for a complex with molecular $C_{\mathrm{s}}$ symmetry, $\mathrm{Pn}^{*} \mathrm{MXY}$.

Crystals grown from a benzene solution of 5 at $25{ }^{\circ} \mathrm{C}$ were identified as $\mathrm{Pn}^{*} \mathrm{ZrCl}\left(\mathrm{O}-2,6{ }^{t}{ }^{\mathrm{Bu}}-\mathrm{C}_{6} \mathrm{H}_{3}\right) \cdot \mathrm{LiCl}(\mathrm{tmeda})$ by a single crystal X-ray diffraction study, where tmeda binds to the chloride ligands to create a stable diamond core (Fig. 1 and Table 1). The $\mathrm{Zr}-\mathrm{O}$ distance is comparable to $\mathrm{Pn}{ }^{*} \mathrm{ZrCl}(\mathrm{O}-2,6$ Me- $\left.\mathrm{C}_{6} \mathrm{H}_{3}\right)$ and $\mathrm{Cp}_{2} \mathrm{ZrCl}\left(\mathrm{O}-2,6-{ }^{t} \mathrm{Bu}^{-} \mathrm{C}_{6} \mathrm{H}_{3}\right)$ (2.0399(9), 1.9844(14) and 2.008(2) A respectively), with comparable $\mathrm{Zr}-\mathrm{Cl}$ distances (2.5635(3), 2.5767(5) and 2.4642(11) $\AA$ respectively). ${ }^{53}$ The

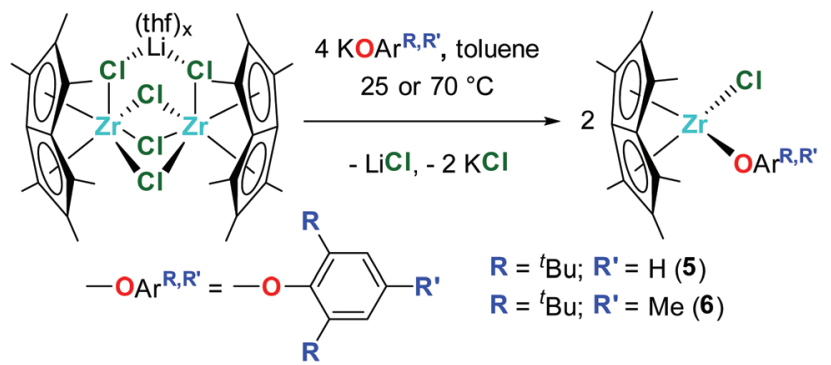

Chart 3 Synthesis of $\mathrm{Pn} * \mathrm{ZrCl}\left(\mathrm{O}-2,6-{ }^{t} \mathrm{Bu}-\mathrm{C}_{6} \mathrm{H}_{3}\right)$ (5) and $\mathrm{Pn} * \mathrm{ZrCl}$ $\left(\mathrm{O}-2,6-{ }^{t} \mathrm{Bu}-4-\mathrm{Me}-\mathrm{C}_{6} \mathrm{H}_{2}\right)(6)$.

$\mathrm{Pn}^{*}{ }_{\text {cent }}$ distances are longer than for 2, 3 and $\mathrm{Pn}{ }^{*} \mathrm{ZrCl}(\mathrm{O}-2,6$ Me- $\mathrm{C}_{6} \mathrm{H}_{3}$ ) (average values of 2.1446(3), 2.089, 2.0936(9) and 2.1138(9) A respectively), likely due to the increased steric bulk of the aryloxide ligand. The $\mathrm{Zr}-\mathrm{O}-\mathrm{C}$ angle is smaller than for 2, 3 and $\mathrm{Pn}^{*} \mathrm{ZrCl}\left(\mathrm{O}-2,6-\mathrm{Me}-\mathrm{C}_{6} \mathrm{H}_{3}\right)$, with the aryloxide group directed towards the Pn* ligand (152.49(9), 164.2(9), 165.20(11) and $174.38(6)^{\circ}$ respectively). Single crystals of 6 suitable for a single crystal X-ray diffraction study were grown from a $-30{ }^{\circ} \mathrm{C}$ toluene solution (Fig. 1 and Table 1). The $\mathrm{Zr}-\mathrm{O}$ bond length is comparable to $\mathrm{Pn}^{*} \mathrm{ZrCl}\left(\mathrm{O}-2,6-\mathrm{Me}^{-} \mathrm{C}_{6} \mathrm{H}_{3}\right)$ (1.9822(11) and 1.9796(14) $\AA$ respectively), as are the $\mathrm{Zr}-\mathrm{Pn}^{*}{ }_{\text {cent }}$ distances (average values of $2.1075(8)$ and $2.1138(9) \AA)$, which is likely due to the similar size of the aryloxide ligands. The aryloxide group points away from the $\mathrm{Pn}^{*}$ ligand with a $\mathrm{Zr}-\mathrm{C}-\mathrm{O}$ angle of $159.47(10)^{\circ}$.

\section{Synthesis and characterisation of $\mathbf{P n}^{*} \mathbf{M C p}^{\mathrm{R}}(\mathrm{OR})$}

$\mathrm{Pn}^{*} \mathrm{ZrCp}\left(\mathrm{O}^{t} \mathrm{Bu}\right)(7), \mathrm{Pn}^{*} \mathrm{ZrCp}\left(\mathrm{O}-2,6-\mathrm{Me}^{-} \mathrm{C}_{6} \mathrm{H}_{3}\right)(8)$ and $\mathrm{Pn}{ }^{*} \mathrm{ZrCp}$ $\left(\mathrm{O}-2,6{ }^{-}{ }^{i} \mathrm{Pr}-\mathrm{C}_{6} \mathrm{H}_{3}\right)(9)$ were prepared by the addition of 1 equivalent KOR $\left(\mathrm{R}={ }^{t} \mathrm{Bu}, 2,6-\mathrm{Me}-\mathrm{C}_{6} \mathrm{H}_{3}\right.$ and $\left.2,6{ }^{i}{ }^{i} \mathrm{Pr}-\mathrm{C}_{6} \mathrm{H}_{3}\right)$ to 1 equivalent $\mathrm{Pn}^{*} \mathrm{ZrCp}(\mathrm{Cl})$, (Chart 4). The ${ }^{1} \mathrm{H}$ NMR spectra display three sharp singlets in a ratio of $6: 6: 6$ between 1.84 and $2.05 \mathrm{ppm}$ corresponding to the $\mathrm{Pn}^{*}$ methyl protons, where two singlets define the non-wingtip methyl groups, and one singlet defines the wingtip methyl groups (Fig. S11, S13 and $\mathrm{S} 15 \dagger)$. This splitting pattern is consistent with molecules of $C_{\mathrm{s}}$ symmetry and has been reported previously for $\mathrm{Pn}^{*} \mathrm{TiCl}(\mathrm{OAr})$ and $\mathrm{Pn}^{*} \mathrm{ZrCp}^{\mathrm{R}}(\mathrm{Cl})$ complexes. ${ }^{44,47}$ The cyclopentadienyl protons are observed as singlets at approximately $5.6 \mathrm{ppm}$, with other features of the -OR groups present as expected; a singlet at $1.19 \mathrm{ppm}$ for $\mathrm{O}^{t} \mathrm{Bu}$, a singlet at $2.05 \mathrm{ppm}$, a triplet at $6.81 \mathrm{ppm}$ and a doublet at $7.18 \mathrm{ppm}$ for $\mathrm{O}-2,6-\mathrm{Me}^{-} \mathrm{C}_{6} \mathrm{H}_{3}$, and

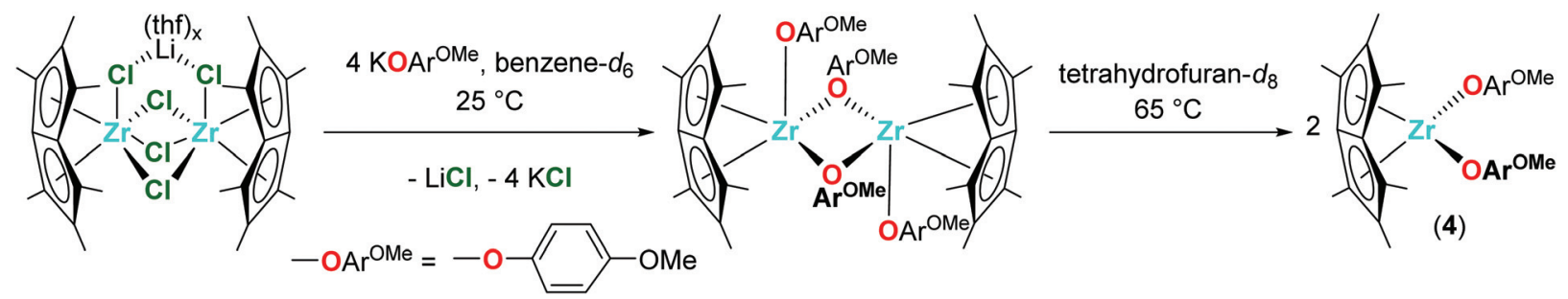

Scheme 1 Synthesis of $\mathrm{Pn}{ }^{\star} \mathrm{Zr}\left(\mathrm{O}-4-\mathrm{Me}-\mathrm{C}_{6} \mathrm{H}_{4}\right)_{2}(4)$ via $\left[\mathrm{Pn}{ }^{*} \mathrm{Zr}\left(\mathrm{O}-4-\mathrm{Me}-\mathrm{C}_{6} \mathrm{H}_{4}\right)_{2}\right]_{2}\left(4^{\prime}\right)$. 


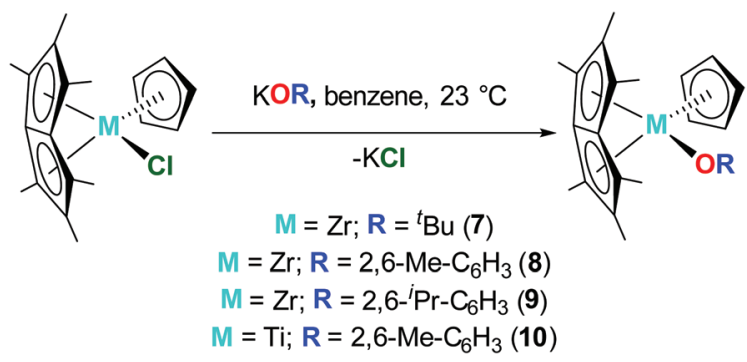

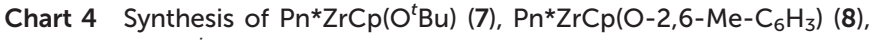
$\mathrm{Pn} * \mathrm{ZrCp}\left(\mathrm{O}-2,6-{ }^{i} \mathrm{Pr}-\mathrm{C}_{6} \mathrm{H}_{3}\right)$ (9) and $\mathrm{Pn}{ }^{*} \mathrm{TiCp}\left(\mathrm{O}-2,6-\mathrm{Me}-\mathrm{C}_{6} \mathrm{H}_{3}\right)(10)$.

doublets at 1.21 and $1.33 \mathrm{ppm}$, a septet at $2.93 \mathrm{ppm}$, a triplet at $6.97 \mathrm{ppm}$ and a doublet at $7.17 \mathrm{ppm}$ for $\mathrm{O}-2,6-{ }^{\mathrm{i}} \mathrm{Pr}^{-} \mathrm{C}_{6} \mathrm{H}_{3}$.

$\mathrm{Pn}^{*} \mathrm{TiCp}\left(\mathrm{O}-2,6-\mathrm{Me}-\mathrm{C}_{6} \mathrm{H}_{3}\right)$ (10) was prepared by the reaction of 1 equivalent $\mathrm{Pn}^{*} \mathrm{TiCp}(\mathrm{Cl})$ with 1.2 equivalents KO-2,6-Me$\mathrm{C}_{6} \mathrm{H}_{3}$. Following work up, 10 was isolated as a brown crystalline solid in $34 \%$ yield. The ${ }^{1} \mathrm{H}$ NMR spectrum shows two singlets at 1.70 and $1.97 \mathrm{ppm}$, corresponding to two overlapping $\mathrm{Pn}^{*}$ methyl resonances and an overlapping $\mathrm{Pn}^{*}$ methyl and aryloxide methyl resonance respectively (Fig. S17†), as confirmed by 2D NMR spectroscopy. The ${ }^{1} \mathrm{H}$ NMR spectrum also shows a diagnostic singlet resonance at 5.25 ppm corresponding to the cyclopentadienyl protons, and a triplet and doublet at 6.85 and $7.21 \mathrm{ppm}$ respectively corresponding to the aryloxide aromatic protons.

$\mathrm{Pn}^{*} \mathrm{ZrCp}^{\mathrm{Me}}\left(\mathrm{O}-2,6-\mathrm{Me}-\mathrm{C}_{6} \mathrm{H}_{3}\right)(\mathbf{1 1}), \mathrm{Pn}^{*} \mathrm{ZrCp}^{\mathrm{Me}}\left(\mathrm{O}-2,6{ }^{i}{ }^{i} \mathrm{Pr}^{-} \mathrm{C}_{6} \mathrm{H}_{3}\right)$ (12) and $\mathrm{Pn}^{*} \mathrm{ZrCp}^{\mathrm{Me}}\left(\mathrm{O}-2,4-{ }^{t} \mathrm{Bu}-\mathrm{C}_{6} \mathrm{H}_{3}\right)$ (13) were prepared by the addition of 1 equivalent KOR ( $\mathrm{R}=2,6-\mathrm{Me}-\mathrm{C}_{6} \mathrm{H}_{3}, 2,6-{ }^{i} \mathrm{Pr}-\mathrm{C}_{6} \mathrm{H}_{3}$ and $\left.2,4{ }^{t}{ }^{\mathrm{Bu}}-\mathrm{C}_{6} \mathrm{H}_{3}\right)$ to 1 equivalent $\mathrm{Pn}^{*} \mathrm{ZrCp}^{\mathrm{Me}}(\mathrm{Cl})$ (Chart 5). The ${ }^{1} \mathrm{H}$ NMR spectra of 11 and 12 show the diagnostic Pn* resonances as three singlets in a 6:6:6 ratio between 1.84 and 2.01 ppm (Fig. S19 and S21†). The cyclopentadienyl proton resonances are observed as two multiplets between 5.20 and 5.64 ppm while a singlet at approximately 1.85 ppm corresponds to the cyclopentadienyl methyl group. The aryloxide protons are observed as a triplet and doublet at approximately 6.85 and 7.15 ppm respectively, with the aryloxide methyl groups of $\mathbf{1 1}$ observed as a singlet at $2.08 \mathrm{ppm}$ and the isopropyl groups of 12 observed as two doublets at 1.21 and $1.35 \mathrm{ppm}$ and a septet at $2.93 \mathrm{ppm}$. Due to changes in symmetry, the ${ }^{1} \mathrm{H}$ NMR spectrum of 13 shows the $\mathrm{Pn}^{*}$ resonances

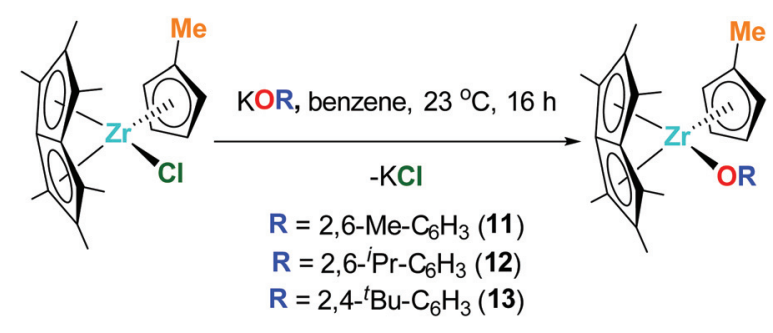

Chart 5 Synthesis of $\mathrm{Pn} * \mathrm{ZrCp}^{\mathrm{Me}}\left(\mathrm{O}-2,6-\mathrm{Me}-\mathrm{C}_{6} \mathrm{H}_{3}\right)$ (11), $\mathrm{Pn} * \mathrm{ZrCp}^{\mathrm{Me}}\left(\mathrm{O}-2,6-{ }^{i} \mathrm{Pr}-\mathrm{C}_{6} \mathrm{H}_{3}\right)$ (12) and $\mathrm{Pn}{ }^{\star} \mathrm{ZrCp}^{\mathrm{Me}}\left(\mathrm{O}-2,4-{ }^{t} \mathrm{Bu}-\mathrm{C}_{6} \mathrm{H}_{3}\right)$ (13).
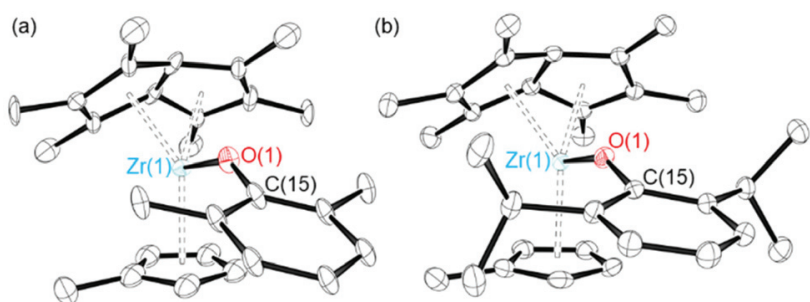

Fig. 2 Solid-state molecular structures of (a) $\mathrm{Pn} * \mathrm{ZrCp}^{\mathrm{Me}}(\mathrm{O}-2,6-\mathrm{Me}-$ $\left.\mathrm{C}_{6} \mathrm{H}_{3}\right)(11)$ and (b) $\mathrm{Pn}{ }^{\star} \mathrm{ZrCp}^{\mathrm{Me}}\left(\mathrm{O}-2,6-{ }^{\mathrm{i}} \mathrm{Pr}-\mathrm{C}_{6} \mathrm{H}_{3}\right)$ (12). $\mathrm{H}$ atoms omitted for clarity. Ellipsoids given at $30 \%$ probability.

as six singlets integration 3 between 1.85 and $2.19 \mathrm{ppm}$ and the cyclopentadienyl proton resonances as three multiplets integration $2: 1: 1$ between 5.30 and 5.65 ppm (Fig. S23†). The aryloxide protons are observed as a doublet, doublet and triplet at 5.99, 7.27 and 7.57 ppm respectively, with the tertbutyl groups appearing as two singlets at 1.42 and $1.60 \mathrm{ppm}$.

Single crystals of 11 and 12 suitable for single crystal X-ray diffraction studies were grown from a pentane solution at $-30{ }^{\circ} \mathrm{C}$. The solid-state molecular structures are shown in Fig. 2. For 11, the crystallographic data clearly confirms the connectivity of the structure and agrees with other experimental data. However, due to the low quality of the X-ray crystallography data, discussion of the metrical parameters is not discussed. 12 shows a longer $\mathrm{Zr}-\mathrm{O}$ bond length and smaller $\mathrm{Zr}-\mathrm{O}-\mathrm{C}$ angle than the complexes discussed previously (2.072(2) $\AA$ and $\left.150.01(19)^{\circ}\right)$, with the aryloxide group pointing away from the $\mathrm{Pn}^{*}$ ligand. The $\mathrm{Zr}-\mathrm{Pn}^{*}{ }_{\text {cent }}$ distances $(2.1302(13)$ and $2.1457(13) \AA)$ are slightly longer than the parent $\mathrm{Pn}^{*} \mathrm{ZrCp}^{\mathrm{Me}}(\mathrm{Cl})$ complex $(2.1062(6)$ and $2.1065(7) \AA$ ), likely due to the increased size of the aryloxide ligand compared to chloride. $^{44}$ The average $\operatorname{Zr}(1)-\mathrm{Pn}^{*}$ cent distance $(2.1379(63) \AA)$ is shorter than the $\operatorname{Zr}(1)-C p_{\text {cent }}$ distance $(2.2173(16) \AA)$, which may be due to the increased electron donating ability of the $\eta^{8}$ permethylpentalene ligand compared to the $\eta^{5}$-cyclopentadienyl ligand. The same trend is also observed for $\mathrm{Pn}^{*} \mathrm{ZrCp}^{\mathrm{Me}}(\mathrm{Cl})$ and $\mathrm{Pn}^{*} \mathrm{TiCp}^{\mathrm{Me}}(\mathrm{Cl}) .{ }^{44}$ The $\mathrm{Zr}-\mathrm{Cp}_{\text {cent }}$ distance of 12 (2.2173(16) $\AA)$ is similar to those reported for $\mathrm{Pn}^{*} \mathrm{ZrCp}^{\mathrm{Me}}(\mathrm{Cl})(2.2219(7) \AA)$ and $\mathrm{Pn}^{*} \mathrm{ZrCp}^{\mathrm{Me}}(\mathrm{Me})(2.2262(11) \AA) .{ }^{44}$ The fold angle of the $\mathrm{Pn}^{*}$ ligand of 12 is smaller than for 2 and 3 (29.72, 32.28 and $32.53^{\circ}$ respectively), which is likely due to the additional electron density provided by the $\mathrm{Cp}$ ligand, and is similar to the $\mathrm{Pn}^{*} \mathrm{ZrCp}^{\mathrm{Me}}(\mathrm{Cl})$ parent compound $\left(30.57^{\circ}\right) .{ }^{44}$ The fold angle is also smaller than $\operatorname{PnZrCp}(\mathrm{Cl})\left(32.74^{\circ}\right)$, caused by the increased inductive donation of $\mathrm{Pn}^{*}$ compared to $\mathrm{Pn}\left(\eta^{8}-\mathrm{C}_{8} \mathrm{H}_{6}\right) .{ }^{54}$

\section{Polymerisation of $\mathrm{L}$ - and rac-lactide}

$\mathrm{Pn}^{*} \mathrm{Zr}\left(\mathrm{O}-2,6-\mathrm{Me}-\mathrm{C}_{6} \mathrm{H}_{3}\right)_{2}$ (2), $\mathrm{Pn}{ }^{*} \mathrm{Zr}\left(\mathrm{O}-2,6-{ }^{i} \mathrm{Pr}-\mathrm{C}_{6} \mathrm{H}_{3}\right)_{2}$ (3), $\mathrm{Pn}{ }^{*} \mathrm{ZrCl}$ $\left(\mathrm{O}-2,6-{ }^{t} \mathrm{Bu}-4-\mathrm{Me}-\mathrm{C}_{6} \mathrm{H}_{2}\right) \quad$ (6), $\quad \mathrm{Pn}{ }^{*} \mathrm{ZrCp}\left(\mathrm{O}^{t} \mathrm{Bu}\right) \quad(7), \quad \mathrm{Pn}^{*} \mathrm{ZrCp}$ $\left(\mathrm{O}-2,6-{ }^{i} \mathrm{Pr}^{-} \mathrm{C}_{6} \mathrm{H}_{3}\right) \quad$ (9), ${ }^{*}$ TiCp $\left(\mathrm{O}-2,6-\mathrm{Me}-\mathrm{C}_{6} \mathrm{H}_{3}\right) \quad$ (10) and $\mathrm{Pn}^{*} \mathrm{ZrCp}^{\mathrm{Me}}\left(\mathrm{O}-2,6-{ }^{i} \mathrm{Pr}^{-} \mathrm{C}_{6} \mathrm{H}_{3}\right)$ (12) were studied as initiators for the ring-opening polymerisation (ROP) of $\mathrm{L}$-lactide, and 2, 3, 6, 7 and $\mathbf{1 0}$ were studied as initiators for ROP of rac-lactide. The results are summarised in Fig. 3-7, S25-S34 $\dagger$ and Tables 2, 3 


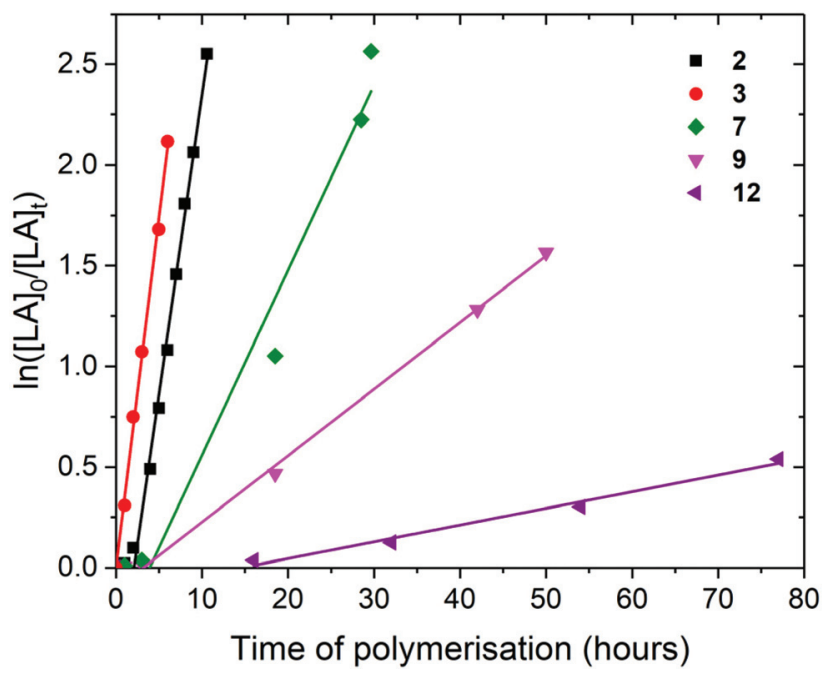

Fig. $3 \ln \left(\left([\mathrm{LA}]_{0} /[\mathrm{LA}]_{t}\right)\right.$ as a function of time of polymerisation for the ROP of L-lactide using $\mathrm{Pn}{ }^{*} \mathrm{Zr}\left(\mathrm{O}-2,6-\mathrm{Me}-\mathrm{C}_{6} \mathrm{H}_{3}\right)_{2}\left(2\right.$, black square, $k_{\mathrm{obs}}=$ $\left.0.30 \pm 0.01 \mathrm{~h}^{-1}\right), \mathrm{Pn} * \operatorname{Zr}\left(\mathrm{O}-2,6-{ }^{i} \mathrm{Pr}-\mathrm{C}_{6} \mathrm{H}_{3}\right)_{2}$ (3, red circle), $k_{\mathrm{obs}}=0.35 \pm$ $\left.0.01 \mathrm{~h}^{-1}\right), \mathrm{Pn}{ }^{*} \mathrm{ZrCp}\left(\mathrm{O}^{t} \mathrm{Bu}\right)\left(7\right.$, green diamond, $\left.k_{\mathrm{obs}}=0.09 \pm 0.01 \mathrm{~h}^{-1}\right)$, $\mathrm{Pn} * \mathrm{ZrCp}\left(\mathrm{O}-2,6-{ }_{-}^{i} \mathrm{Pr}-\mathrm{C}_{6} \mathrm{H}_{3}\right)$ (9, pink down triangle, $k_{\text {obs }}=0.03 \pm$ $\left.0.001 \mathrm{~h}^{-1}\right)$ and $\mathrm{Pn} * \mathrm{ZrCp}{ }^{\mathrm{Me}}\left(\mathrm{O}-2,6-{ }^{i} \mathrm{Pr}-\mathrm{C}_{6} \mathrm{H}_{3}\right)\left(12\right.$, purple left triangle, $k_{\text {obs }}$ $=0.01 \pm 0.001 \mathrm{~h}^{-1}$ ). Polymerisation conditions: $80^{\circ} \mathrm{C},[\mathrm{LA}]_{0} /[\mathrm{M}]_{0}=50$, $[\mathrm{LA}]_{0}=0.5 \mathrm{M}$ and benzene- $d_{6}$.

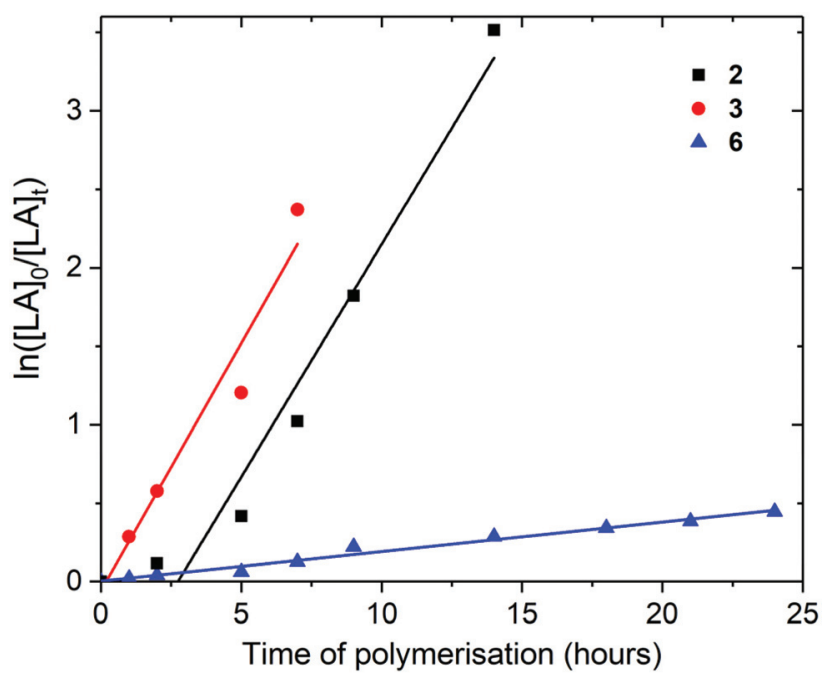

Fig. $4 \ln \left([L A]_{0} /[L A]_{t}\right)$ as a function of time of polymerisation for the ROP of L-lactide using $\mathrm{Pn} * \mathrm{Zr}\left(\mathrm{O}-2,6-\mathrm{Me}-\mathrm{C}_{6} \mathrm{H}_{3}\right)_{2}\left(2\right.$, black square, $k_{\text {obs }}=0.30 \pm$ $\left.0.03 \mathrm{~h}^{-1}\right), \mathrm{Pn} * \mathrm{Zr}\left(\mathrm{O}-2,6-{ }^{i} \mathrm{Pr}-\mathrm{C}_{6} \mathrm{H}_{3}\right)_{2}\left(3\right.$, red circle, $\left.k_{\text {obs }}=0.32 \pm 0.04 \mathrm{~h}^{-1}\right)$, and $\mathrm{Pn} * \mathrm{ZrCl}\left(\mathrm{O}-2,6-{ }^{t} \mathrm{Bu}-4-\mathrm{Me}-\mathrm{C}_{6} \mathrm{H}_{2}\right)\left(6\right.$, blue triangle, $k_{\text {obs }}=0.02 \pm$ $\left.0.001 \mathrm{~h}^{-1}\right)$. Polymerisation conditions: $80{ }^{\circ} \mathrm{C},[\mathrm{LA}]_{0} /[\mathrm{M}]_{0}=200,[\mathrm{LA}]_{0}=$ $2.0 \mathrm{M}$ and benzene- $d_{6}$.

and S3-S32.† Polymerisations were conducted in Young's tap NMR spectroscopy tubes at $80{ }^{\circ} \mathrm{C}$ in benzene- $d_{6}$ with an initial lactide to catalyst ratio $\left([\mathrm{LA}]_{0} /[\mathrm{M}]_{0}\right)$ of 50 or 200 and an initial lactide monomer concentration ([LA $\left.]_{0}\right)$ of 0.5 or $2.0 \mathrm{M}$. Plots of $\ln \left([\mathrm{LA}]_{0} /[\mathrm{LA}]_{t}\right) v s$. time revealed linear relationships indicating first-order dependence with respect to monomer concentration

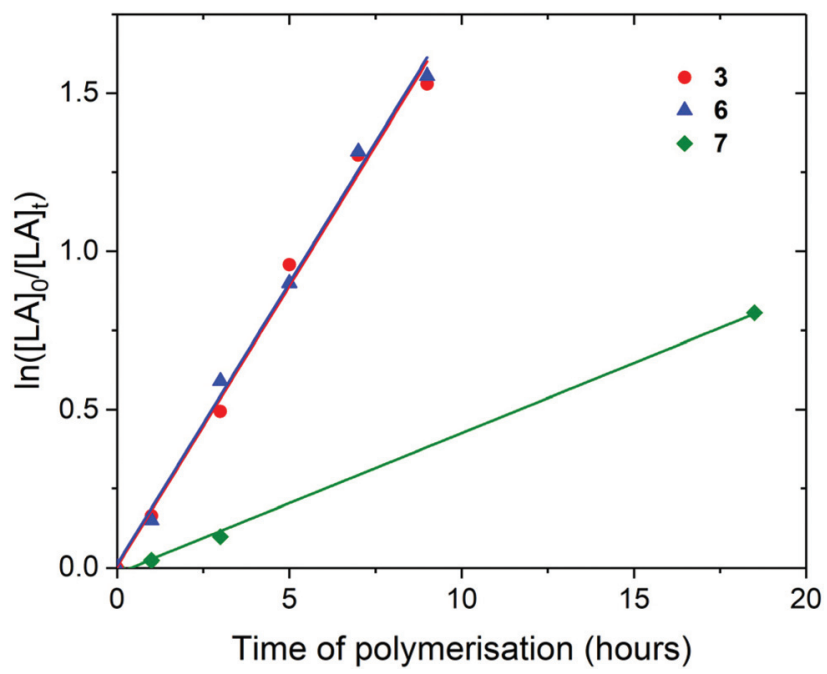

Fig. $5 \ln \left([\mathrm{LA}]_{0} /[\mathrm{LA}]_{t}\right)$ as a function of time of polymerisation for the ROP of rac-lactide using $\mathrm{Pn}{ }^{*} \mathrm{Zr}\left(\mathrm{O}-2,6-{ }^{i} \mathrm{Pr}-\mathrm{C}_{6} \mathrm{H}_{3}\right)_{2}$ (3, red circle, $k_{\text {obs }}=0.18 \pm$ $\left.0.01 \mathrm{~h}^{-1}\right), \mathrm{Pn} * \mathrm{ZrCl}\left(\mathrm{O}-2,6-{ }^{t} \mathrm{Bu}-4-\mathrm{Me}-\mathrm{C}_{6} \mathrm{H}_{2}\right)\left(6\right.$, blue triangle, $k_{\text {obs }}=0.18 \pm$ $\left.0.01 \mathrm{~h}^{-1}\right)$ and $\mathrm{Pn}{ }^{\star} \mathrm{ZrCp}\left(\mathrm{O}^{t} \mathrm{Bu}\right)\left(7\right.$, green diamond, $k_{\mathrm{obs}}=0.04 \pm$ $\left.0.001 \mathrm{~h}^{-1}\right)$. Polymerisation conditions: $80^{\circ} \mathrm{C},[\mathrm{LA}]_{0} /[\mathrm{M}]_{0}=50,[\mathrm{LA}]_{0}=0 . \overline{5}$ $M$ and benzene- $d_{6}$.

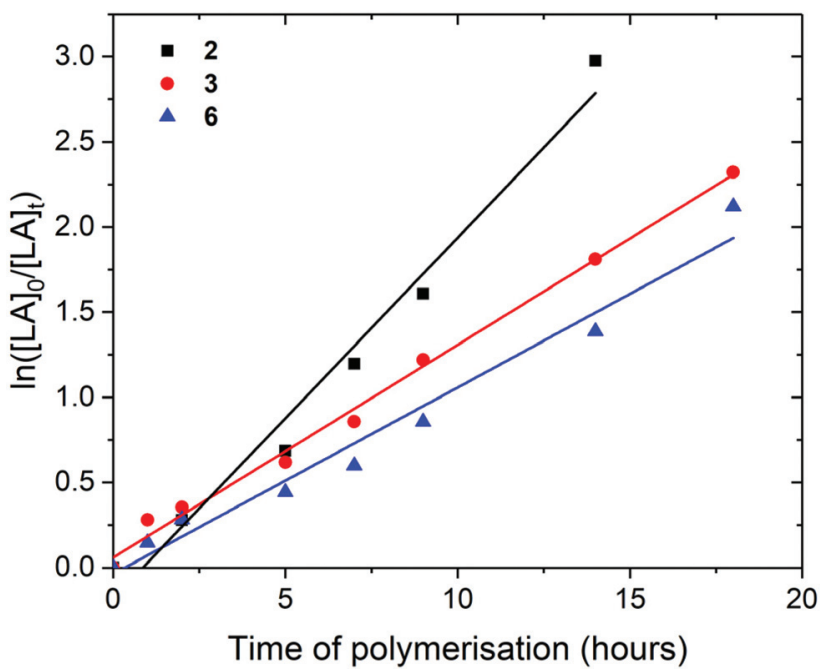

Fig. $6 \ln \left([L A]_{0} /[L A]_{t}\right)$ as a function of time of polymerisation for the ROP of rac-lactide using $\mathrm{Pn} * \mathrm{Zr}\left(\mathrm{O}-2,6-\mathrm{Me}-\mathrm{C}_{6} \mathrm{H}_{3}\right)_{2}\left(2\right.$, black square, $k_{\text {obs }}=0.21$ $\left.\pm 0.02 \mathrm{~h}^{-1}\right), \mathrm{Pn} * \mathrm{Zr}\left(\mathrm{O}-2,6-{ }^{i} \mathrm{Pr}-\mathrm{C}_{6} \mathrm{H}_{3}\right)_{2}\left(3\right.$, red circle, $\left.k_{\text {obs }}=0.12 \pm 0.01 \mathrm{~h}^{-1}\right)$, and $\mathrm{Pn} * \mathrm{ZrCl}\left(\mathrm{O}-2,6-{ }^{t} \mathrm{Bu}-4-\mathrm{Me}-\mathrm{C}_{6} \mathrm{H}_{2}\right)$ (6, blue triangle, $k_{\mathrm{obs}}=0.11 \pm$ $0.01 \mathrm{~h}^{-1}$ ). Polymerisation conditions: $80{ }^{\circ} \mathrm{C},[\mathrm{LA}]_{0} /[\mathrm{M}]_{0}=200,[\mathrm{LA}]_{0}=2.0$ $M$ and benzene- $d_{6}$.

(Fig. 3-6). The gradients of the $\ln \left([\mathrm{LA}]_{0} /[\mathrm{LA}]_{t}\right)$ vs. time plots afforded the observed first order rate constants, $k_{\text {obs }}$.

For the polymerisation of L-lactide with $[\mathrm{LA}]_{0} /[\mathrm{M}]_{0}$ of 50 and $[\mathrm{LA}]_{0}$ of $0.5 \mathrm{M}$, rate of polymerisation followed the order 3, 2 , 7, 9 and 12. Complex 2 required a 2 hours initiation period, after which 2 and 3 showed very similar rates for the ROP of L-lactide; $k_{\text {obs }}$ of 0.30 and $0.35 \mathrm{~h}^{-1}$ respectively, taking 10.6 and 


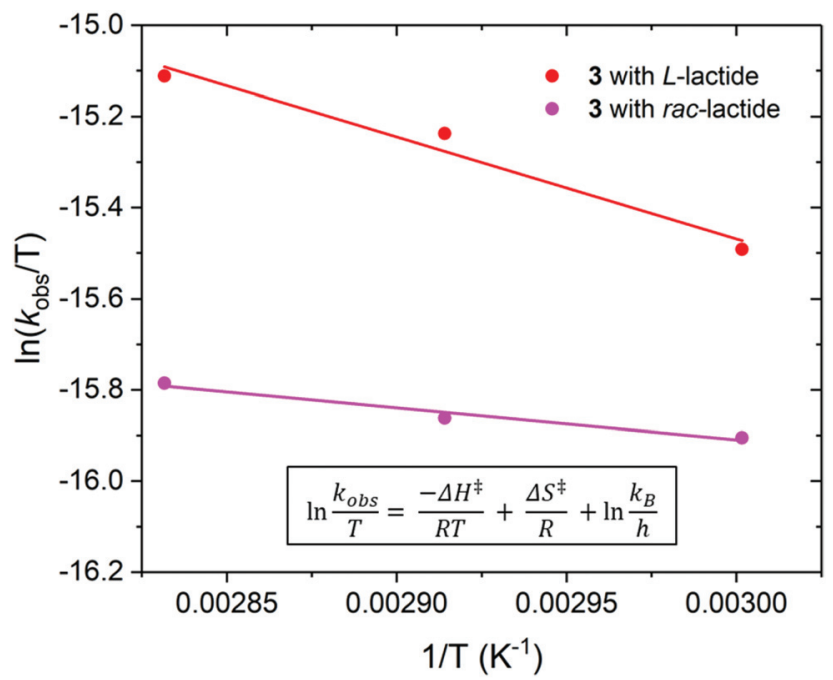

Fig. 7 Eyring plot of $\ln \left(k_{\mathrm{obs}} / T\right)$ as a function of $1 / T$ for the polymerisation of $\mathrm{L}-\left(\right.$ red) and rac-lactide (pink) using $\mathrm{Pn} * \mathrm{Zr}\left(\mathrm{O}-2,6-{ }^{i} \mathrm{Pr}-\mathrm{C}_{6} \mathrm{H}_{3}\right)_{2}$ (3). L-Lactide: $\Delta H^{\ddagger}=19 \pm 3 \mathrm{~kJ} \mathrm{~mol}^{-1}$ and $\Delta S^{\ddagger}=-270 \pm 10 \mathrm{~J} \mathrm{~mol}^{-1} \mathrm{~K}^{-1}$. racLactide: $\Delta H^{\ddagger}=6 \pm 1 \mathrm{~kJ} \mathrm{~mol}^{-1}$ and $\Delta S^{\ddagger}=-312 \pm 3 \mathrm{~J} \mathrm{~mol}^{-1} \mathrm{~K}^{-1}$. Polymerisation conditions: $[\mathrm{LA}]_{0} /[\mathrm{M}]_{0}=200,[\mathrm{LA}]_{0}=2.0 \mathrm{M}$ and benzene$d_{6}$.

6 hours to reach full conversion (92 and 88\%) (Fig. 3). This suggests that the increase in the steric bulk of the aryloxide substituent from methyl to isopropyl does not hinder L-lactide monomer insertion. When compared to the corresponding
$\mathrm{Pn}^{*}(\mathrm{H}) \operatorname{Zr}(\mathrm{OAr})$ complexes, 2 shows polymerisation activity $37 \%$

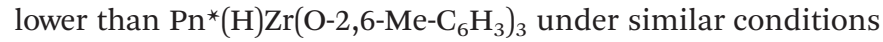
$\left(k_{\text {obs }}\right.$ of $\left.0.48 \mathrm{~h}^{-1}\right)$ and 3 shows polymerisation activity $10 \%$ lower than $\mathrm{Pn}^{*}(\mathrm{H}) \mathrm{Zr}\left(\mathrm{O}-2,6-{ }^{i}{ }^{\mathrm{Pr}}-\mathrm{C}_{6} \mathrm{H}_{3}\right)_{3}\left(k_{\text {obs }}\right.$ of $\left.0.39 \mathrm{~h}^{-1}\right){ }^{56}$

These initiators show polymerisation activities lower than zirconium complexes bearing OSSO-type ligands (up to $74 \%$ conversion with $k_{\text {obs }}$ up to $0.50 \mathrm{~h}^{-1}$ at $80{ }^{\circ} \mathrm{C}$ after 3 hours with $[\mathrm{LA}] /[\mathrm{M}]_{0}$ of 100$)^{57}$ and lower than the neutral bis(ester enolate) complex ${ }^{\mathrm{Ph} 2} \mathrm{CB}(\mathrm{Cp}$, Flu $) \mathrm{Zr}\left(\mathrm{OC}\left(\mathrm{O}^{\mathrm{i}} \mathrm{Pr}\right) \mathrm{CMe}_{2}\right)_{2}$ ( $92 \%$ conversion after 105 minutes at $80{ }^{\circ} \mathrm{C}$ with $\left.[\mathrm{LA}]_{0} /[\mathrm{M}]_{0}=50\right) .{ }^{58}$ However, they showed faster polymerisation activities than aryloxide $\mathrm{Cp}_{2} \mathrm{ZrMe}\left(\mathrm{O}-2,6-\mathrm{Me}-\mathrm{C}_{6} \mathrm{H}_{3}\right)$, which displayed $k_{\text {obs }}$ of $0.029 \mathrm{~h}^{-1}$ at $80^{\circ} \mathrm{C}$ with $[\mathrm{LA}]_{0} /[\mathrm{M}]_{0}=50 .{ }^{59}$

$\mathrm{Pn}^{*} \mathrm{ZrCp}^{\mathrm{R}}\left(\mathrm{OR}^{\prime}\right)$ complexes 7, 9 and $\mathbf{1 2}$ showed much lower $k_{\text {obs }}$ than $\mathrm{Pn}^{*} \mathrm{Zr}(\mathrm{OAr})_{2}$ complexes 2 and $3(0.09,0.03$ and $0.01 \mathrm{~h}^{-1}$ respectively), and required longer initiation periods ( 3,3 and 16 hours respectively), indicating that the addition of a non-initiating cyclopentadienyl ligand significantly reduces polymerisation activity. This is opposite to the trend found for ethylene polymerisation using these types of complexes, where polymerisation activity increased with increasing electron donating ability of the ancillary ligands due to increased stabilisation of the positively charged olefin polymerisation intermediates. ${ }^{44}$ For lactide polymerisation, it may be that the increased electron donating ability of the cyclopentadienyl ligands reduces the Lewis acidity of the metal centre, leading to lower rates of lactide insertion and decreases in polymerisation activity. This is in contrast to some yttrium initiators,

Table 2 Polymerisation of L-lactide using $\mathrm{Pn} * \mathrm{Zr}\left(\mathrm{O}-2,6-\mathrm{Me}-\mathrm{C}_{6} \mathrm{H}_{3}\right)_{2}(2), \mathrm{Pn} * \mathrm{Zr}\left(\mathrm{O}-2,6-{ }^{i} \mathrm{Pr}-\mathrm{C}_{6} \mathrm{H}_{3}\right)_{2}(3), \mathrm{Pn} * \mathrm{ZrCl}\left(\mathrm{O}-2,6-{ }^{t} \mathrm{Bu}-4-\mathrm{Me}-\mathrm{C}_{6} \mathrm{H}_{2}\right)(6), \mathrm{Pn} * \mathrm{ZrCp}$ $\left(\mathrm{O}^{t} \mathrm{Bu}\right)(7), \mathrm{Pn}{ }^{\star} \mathrm{ZrCp}\left(\mathrm{O}-2,6-{ }^{i} \mathrm{Pr}-\mathrm{C}_{6} \mathrm{H}_{3}\right)(9)$ and $\mathrm{Pn}{ }^{\star} \mathrm{ZrCp}\left(\mathrm{O}-2,6-{ }^{i} \mathrm{Pr}-\mathrm{C}_{6} \mathrm{H}_{3}\right)(12)^{a}$

\begin{tabular}{|c|c|c|c|c|c|c|c|c|}
\hline Initiator & {$[\mathrm{LA}]_{\mathrm{o}} /[\mathrm{M}]_{0}$} & {$[\mathrm{LA}]_{0}(\mathrm{M})$} & Time (h) & Conversion $^{b}(\%)$ & $k_{\mathrm{obs}}\left(\mathrm{h}^{-1}\right)$ & $M_{\mathrm{n}}(\operatorname{calcd})^{c}\left(\mathrm{~g} \mathrm{~mol}^{-1}\right)$ & $M_{\mathrm{n}}(\mathrm{GPC})^{d}\left(\mathrm{~g} \mathrm{~mol}^{-1}\right)$ & $M_{\mathrm{w}} / M_{\mathrm{n}}{ }^{d}$ \\
\hline 2 & 50 & 0.5 & 10.6 & 92 & $0.30 \pm 0.01$ & - & - & - \\
\hline 3 & 50 & 0.5 & 6 & 88 & $0.35 \pm 0.01$ & 6520 & 17398 & 1.62 \\
\hline 7 & 50 & 0.5 & 30 & 92 & $0.09 \pm 0.01$ & - & - & - \\
\hline 9 & 50 & 0.5 & 50 & 79 & $0.03 \pm 0.001$ & - & - & - \\
\hline 12 & 50 & 0.5 & 164 & 85 & $0.01 \pm 0.001$ & - & - & - \\
\hline 2 & 200 & 2.0 & 21 & 98 & $0.30 \pm 0.03$ & 28374 & 30709 & 1.37 \\
\hline 3 & 200 & 2.0 & 28 & 98 & $0.32 \pm 0.04$ & 28430 & 31327 & 1.28 \\
\hline 6 & 200 & 2.0 & 24 & 36 & $0.02 \pm 0.001$ & 10598 & 12950 & 1.45 \\
\hline
\end{tabular}

${ }^{a}$ Polymerisation conditions: $80{ }^{\circ} \mathrm{C}$ and benzene- $d_{6} \cdot{ }^{b}$ Measured by ${ }^{1} \mathrm{H}$ NMR spectroscopic analysis. ${ }^{c} M_{\mathrm{n}}(\mathrm{calcd})=\left(M_{\mathrm{LA}} \times[\mathrm{LA}]_{0} /[\mathrm{M}]_{0} \times(\right.$ conv . $(\%) / 100)+M_{\text {end group. }}{ }^{d}$ Determined by GPC in chloroform at $30{ }^{\circ} \mathrm{C}$ against polystyrene standards $\left(M_{\mathrm{n}}\right.$ values are corrected by a factor of 0.58$) .{ }^{55}$

Table 3 Polymerisation of rac-lactide using $\mathrm{Pn} * \mathrm{Zr}\left(\mathrm{O}-2,6-\mathrm{Me}-\mathrm{C}_{6} \mathrm{H}_{3}\right)_{2}$ (2), $\mathrm{Pn} * \mathrm{Zr}\left(\mathrm{O}-2,6-{ }^{i} \mathrm{Pr}-\mathrm{C}_{6} \mathrm{H}_{3}\right)_{2} \quad(3), \mathrm{Pn} * \mathrm{ZrCl}\left(\mathrm{O}-2,6-{ }^{t} \mathrm{Bu}-4-\mathrm{Me}-\mathrm{C}_{6} \mathrm{H}_{2}\right) \quad(6)$ and $\mathrm{Pn} * \mathrm{ZrCp}\left(\mathrm{O}^{t} \mathrm{Bu}\right)(7)^{a}$

\begin{tabular}{|c|c|c|c|c|c|c|c|c|c|}
\hline Initiator & {$[\mathrm{LA}]_{\mathrm{o}} /[\mathrm{M}]_{0}$} & {$[\mathrm{LA}]_{0}(\mathrm{M})$} & Time (h) & Conversion(\%) & $k_{\text {obs }}\left(\mathrm{h}^{-1}\right)$ & $M_{\mathrm{n}}\left(\right.$ calcd $^{b}\left(\mathrm{~g} \mathrm{~mol}^{-1}\right)$ & $M_{\mathrm{n}}(\mathrm{GPC})^{c}\left(\mathrm{~g} \mathrm{~mol}^{-1}\right)$ & $M_{\mathrm{w}} / M_{\mathrm{n}}^{\mathrm{d}}$ & $P_{\mathrm{r}}$ \\
\hline 3 & 50 & 0.5 & 9 & 78 & $0.18 \pm 0.01$ & 5800 & 9930 & 1.57 & - \\
\hline 6 & 50 & 0.5 & 9 & 79 & $0.18 \pm 0.01$ & 5914 & 6617 & 1.56 & - \\
\hline 7 & 50 & 0.5 & 30 & 87 & $0.04 \pm 0.001$ & - & - & - & - \\
\hline 2 & 200 & 2.0 & 21 & 98 & $0.21 \pm 0.02$ & 28374 & 25275 & 1.23 & 0.66 \\
\hline 3 & 200 & 2.0 & 30 & 97 & $0.12 \pm 0.01$ & 28141 & 25509 & 1.14 & 0.54 \\
\hline 6 & 200 & 2.0 & 24 & 95 & $0.11 \pm 0.01$ & 27607 & 26747 & 1.38 & 0.68 \\
\hline
\end{tabular}

${ }^{a}$ Polymerisation conditions: $80{ }^{\circ} \mathrm{C}$ and benzene- $d_{6} \cdot{ }^{b} M_{\mathrm{n}}$ (calcd) $=\left(M_{\mathrm{LA}} \times[\mathrm{LA}]_{0} /[\mathrm{M}]_{0} \times(\right.$ conv. $(\%) / 100)+M_{\text {end group }}{ }^{c}$ Determined by GPC in chloroform at $30^{\circ} \mathrm{C}$ against polystyrene standards $\left(M_{\mathrm{n}}\right.$ values are corrected by a factor of 0.58$) .{ }^{55}$ 
where initiators bearing more electron-donating phosphasalen ligands showed higher activities than initiators bearing salen ligands. ${ }^{23,60}$ Alkoxide 7 shows a faster rate of polymerisation than aryloxides $\mathbf{9}$ and $\mathbf{1 2}$ (92, 79 and 85\% conversion after 30, 50 and $164 \mathrm{~h}$ respectively), as has been seen before for (Ind) ${ }_{2} \mathrm{ZrMe}(\mathrm{OR})$ complexes $\left(k_{\text {obs }}\right.$ of 0.06 and $0.22 \mathrm{~h}^{-1}$ for $\mathrm{R}=$ 2,6-Me- $\mathrm{C}_{6} \mathrm{H}_{3}$ and ${ }^{t} \mathrm{Bu}$ respectively), and is likely due to the increased steric bulk of the aryloxide substituent inhibiting monomer coodination. ${ }^{59}$

The faster polymerisation rate of $\mathbf{9}$ compared to $\mathbf{1 2}$ is likely due to the increased electron donating ability of methylcyclopentadienyl compared to unsubstituted cyclopentadienyl, which further reduces the Lewis acidity of the metal centre and inhibits initiation. The titanium analogue $\mathrm{Pn}^{*} \mathrm{TiCp}(\mathrm{O}-2,6-$ Me- $\mathrm{C}_{6} \mathrm{H}_{3}$ ) (10) shows a very slow rate of polymerisation compared to 9 ( 24 days to react $89 \%$ conversion) and requires a 3 day initiation period (Fig. S25 $\dagger$ ). This trend has also been observed for $\mathrm{Pn}^{*} \mathrm{M}\left(\mathrm{O}-2,6-\mathrm{Me}-\mathrm{C}_{6} \mathrm{H}_{3}\right)_{3}$ initiators where $\mathrm{M}=\mathrm{Ti}$ showed a much lower rate of polymerisation than $\mathrm{M}=\mathrm{Zr}$ $\left(k_{\text {obs }}=0.11\right.$ and $0.48 \mathrm{~h}^{-1}$ respectively), ${ }^{56}$ and for well-defined alkoxotitanium and alkoxozirconium complexes of tetradentate amine-phenolate ligands where polymerisation activity was up to 30 times faster for zirconium initiators compared to titanium. ${ }^{61}$ This effect is attributed the larger, less crowded zirconium centre facilitating approach and coordination of lactide monomers.

For the polymerisation of L-lactide with $[\mathrm{LA}]_{0} /[\mathrm{M}]_{0}$ of 200 and $[\mathrm{LA}]_{0}$ of $2.0 \mathrm{M}$, rate of polymerisation followed the order 3 , 2 and 6 (Fig. 4). As previously discussed for $[\mathrm{LA}]_{0} /[\mathrm{M}]_{0}$ of 50 and $[\mathrm{LA}]_{0}$ of $0.5 \mathrm{M}, 2$ and 3 show very similar rates for the polymerisation of L-lactide ( 0.30 and $0.32 \mathrm{~h}^{-1}$ respectively). Mono (aryloxide) 6 showed a much slower rate of polymerisation than bis(aryloxides) 2 and $3\left(0.02 \mathrm{~h}^{-1}\right)$. These initiators show faster rates of $\mathrm{L}$-lactide polymerisation than the neutral bis (ester enolate)s $\mathrm{Cp}_{2} \mathrm{Zr}\left[\mathrm{OC}\left(\mathrm{O}^{i} \mathrm{Pr}\right) \mathrm{CMe}_{2}\right]_{2}$ and $\mathrm{rac}-\mathrm{EBIZr}\left[\mathrm{OC}\left(\mathrm{C}^{i} \mathrm{Pr}\right)\right.$ $\left.\mathrm{CMe}_{2}\right]_{2}$, which showed 7\% conversion after 26 and 18 hours respectively at $80^{\circ} \mathrm{C}$ with $[\mathrm{LA}]_{0} /[\mathrm{M}]_{0}=200 . .^{58}$

The experimental number averaged molecular weights $\left(M_{\mathrm{n}}\right)$ of the poly-L-lactides produced using 2, 3 and 6 with $[\mathrm{LA}]_{0} /[\mathrm{M}]_{0}$ of 200 show good agreement with the calculated values, suggesting that all the metal centres were active during polymerisation and that only one aryloxide group is involved in polymerisation using 2 and $3 ; M_{\mathrm{n}}$ (calcd) of $28374 \mathrm{~g} \mathrm{~mol}^{-1}$ and $M_{\mathrm{n}}$ (GPC) of $30709 \mathrm{~g} \mathrm{~mol}^{-1}$ for 2 (Table 2). The experimental $M_{\mathrm{n}}$ for the poly-L-lactides produced using 3 with $[\mathrm{LA}]_{0} /[\mathrm{M}]_{0}$ of 50 are approximately triple the calculated $M_{\mathrm{n}}$, suggesting that only a third of complex 3 initiate polymerisation at this concentration. This is confirmed by the molecular weight distributions (MWD $=M_{\mathrm{w}} / M_{\mathrm{n}}$ ) being relatively large in all cases, indicating transesterification processes may be occurring $\left(M_{\mathrm{w}} /\right.$ $\left.M_{\mathrm{n}}=1.28-1.62\right)$. The homonuclear decoupled ${ }^{1} \mathrm{H}$ NMR spectra of the poly-L-lactides produced using 2, 3 and 6 with $[\mathrm{LA}]_{\mathrm{O}} /[\mathrm{M}]_{0}$ of 200 demonstrated that no epimerisation occurred and confirmed the production of isotactic PLA (Fig. S35-S37†).

For the polymerisation of rac-lactide with $[\mathrm{LA}]_{0} /[\mathrm{M}]_{0}$ of 50 and $[\mathrm{LA}]_{0}$ of $0.5 \mathrm{M}$, rate of polymerisation followed the order 3 ,
6 and 7, with 3 and 6 showing identical rates of polymerisation $\left(k_{\text {obs }}\right.$ of $0.18 \mathrm{~h}^{-1}$ ) (Fig. 5). This suggests that the increase in the steric bulk of the aryloxide substituent from isopropyl to tertbutyl does not hinder rac-lactide monomer insertion, neither does the decrease in the number of aryloxide initiation groups. As for the polymerisation of L-lactide, the rate of polymerisation of 7 is slower than $3\left(0.04 \mathrm{~h}^{-1}\right)$, likely due to the decrease in Lewis acidity at the metal centre and the presence of a noninitiating cyclopentadienyl ligand. When compared to the ROP of L-lactide, 3 and 7 displayer slower rates of polymerisation for rac-lactide. As for the polymerisation of L-lactide, the titanium initiator $\mathrm{Pn}{ }^{*} \mathrm{TiCp}\left(\mathrm{O}-2,6-\mathrm{Me}-\mathrm{C}_{6} \mathrm{H}_{3}\right)$ (10) shows a much slower rate of polymerisation than 3, 6 and 7 (24 days to react $79 \%$ conversion) and requires a 3 day initiation period (Fig. S25†). The slower polymerisation activity of Ti compared to $\mathrm{Zr}$ for the ROP of rac-lactide has also been observed for the ROP of rac-lactide using the tetracarbamato complexes $\mathrm{M}\left(\mathrm{O}_{2} \mathrm{CNEt}_{2}\right)_{4}$, where $96 \%$ conversion was achieved after 13 hours at $100{ }^{\circ} \mathrm{C}$ for $\mathrm{M}=\mathrm{Zr}$ and only $31 \%$ for $\mathrm{M}=\mathrm{Ti}^{62}$

These initiators display significantly lower polymerisation activities for the ROP of rac-lactide than $\mathrm{Pn}^{*}(\mathrm{H}) \mathrm{Zr}(\mathrm{rac}$-OCH $\left.\left\{\mathrm{CH}_{3}\right\}_{2} \mathrm{C}_{6} \mathrm{H}_{5}\right)_{3}$ and $\mathrm{Pn} *(\mathrm{H}) \mathrm{Zr}\left(S-\mathrm{OCH}\left\{\mathrm{CH}_{3}\right\}_{2} \mathrm{C}_{6} \mathrm{H}_{5}\right)_{3}$ under similar conditions $\left(k_{\mathrm{obs}}=1.67\right.$ and $1.34 \mathrm{~h}^{-1}$ respectively). ${ }^{56}$ They are also slower rac-lactide polymerisation initiators than some unsymmetrical zirconium metal complexes based on ONNO salalen-type ligands, where up to $99 \%$ conversion of rac-lactide was achieved after 2 hours at $80^{\circ} \mathrm{C}$ with $[\mathrm{LA}]_{0} /[\mathrm{M}]_{0}$ of $100 .^{63,64}$ Complexes 3, 6 and 7 complexes show polymerisation activities more similar to coordinatively unsaturated cationic zirconium benzyl/alkoxide complexes with phosphasalen ligands (up to $93 \%$ conversion after 15 hours at $70{ }^{\circ} \mathrm{C}$ and up to $99 \%$ conversion after 14 hours at $90{ }^{\circ} \mathrm{C}$ with $[\mathrm{LA}]_{0} /[\mathrm{M}]_{0}$ of 100$),{ }^{65}$ and are faster than zirconium complexes of bipyrrolidine derived salan ligands $\left(60 \%\right.$ conversion after 8 hours at $70{ }^{\circ} \mathrm{C}$ with $[\mathrm{LA}]_{0} /[\mathrm{M}]_{0}$ of 100). ${ }^{66}$

The polymerisation of rac-lactide using 3 and 6 was also carried out with $[\mathrm{LA}]_{0} /[\mathrm{M}]_{0}$ of 25 and 10, keeping $[\mathrm{LA}]_{0}$ constant at 0.5 M (Fig. S26 and S27 and Table S4 $\dagger$ ). As expected, $k_{\text {obs }}$ increased with increasing initiator concentration; $k_{\mathrm{obs}}$ of 0.18 , 0.34 and $0.49 \mathrm{~h}^{-1}$ for polymerisation using 3 with $[\mathrm{LA}]_{\mathrm{o}} /[\mathrm{M}]_{0}$ of 50,25 and 10 respectively. The rates of polymerisation of 3 and 6 remained similar with varying initiator concentrations; $k_{\mathrm{obs}}$ of 0.49 and $0.46 \mathrm{~h}^{-1}$ respectively with $[\mathrm{LA}]_{0} /[\mathrm{M}]_{0}$ of 10 . Plots of $-\ln \left(k_{\text {obs }}\right)$ vs. $-\ln \left([\mathrm{M}]_{0}\right.$ is shown in Fig. S28, $\dagger$ gradients of $0.62 \pm$ 0.15 and $0.58 \pm 0.16$ for 3 and 6 respectively are indicative of first-order dependence on the concentration of 3 and 6 . The propagation rate constant $\left(k_{\mathrm{p}}\right)$ of $7.17 \pm 2.29 \mathrm{M}^{-1} \mathrm{~h}^{-1}$ and 6.37 $\pm 2.37 \mathrm{M}^{-1} \mathrm{~h}^{-1}$ for 3 and 6 respectively was calculated from plot of $k_{\text {obs }} v s$. [M] $]_{0}$ (Fig. S29†). The overall rate laws were determined as $-\mathrm{d}[r a c-\mathrm{LA}] / \mathrm{d} t=k_{\mathrm{p}}[r a c-\mathrm{LA}][\mathrm{M}]$.

For the polymerisation of rac-lactide with $[\mathrm{LA}]_{0} /[\mathrm{M}]_{0}$ of 200 and $[\mathrm{LA}]_{0}$ of $2.0 \mathrm{M}$, rate of polymerisation followed the order 2 , 3 and $6 ; k_{\text {obs }}$ of $0.21,0.12$ and $0.11 \mathrm{~h}^{-1}$ with 95,84 and $75 \%$ conversion respectively after 14 hours at $80^{\circ} \mathrm{C}$ (Fig. 6). The catalysts show faster rates of polymerisation than $\mathrm{Zr}\left(\mathrm{O}_{2} \mathrm{CNR}_{2}\right)_{4}$ tetracarbamato complexes; 87 and $88 \%$ for $\mathrm{Zr}\left(\mathrm{O}_{2} \mathrm{CNEt}_{2}\right)_{4}$ and 
$\mathrm{Zr}\left(\mathrm{O}_{2} \mathrm{CN}^{\mathrm{i}} \mathrm{Pr}_{2}\right)_{4}$ respectively after 13 hours at $100{ }^{\circ} \mathrm{C}$ with $[\mathrm{LA}]_{0} /$ $[\mathrm{M}]_{0}$ of $200 .^{62}$ They show similar rates of polymerisation to some zirconium complexes bearing ONSO ligands where up to $98 \%$ conversion of rac-lactide was achieved after 20 hours at $70{ }^{\circ} \mathrm{C}$ with $[\mathrm{LA}]_{0} /[\mathrm{M}]_{0}$ of $300,{ }^{67}$ and to some zirconium complexes bearing phenylene-salalen ligands where up to $99 \%$ conversion was achieved after 24 hours at $70{ }^{\circ} \mathrm{C}$ with $[\mathrm{LA}]_{\mathrm{o}} /[\mathrm{M}]_{0}$ of $300 .{ }^{68}$ In contrast to the ROP of L-lactide, 2 shows a faster rate of polymerisation than 3 for the ROP of rac-lactide, which suggests that 2 may have a more preferential ligand environment for D-lactide monomer insertion than 3. Similar to the polymerisation of L-lactide, 6 shows a slower rate of polymerisation than 2 and 3, which may be due to its increased steric bulk or the reduction in the number of aryloxide groups. Unlike 2 and 3, 6 shows a faster rate of polymerisation for raclactide compared to L-lactide ( 0.11 and $0.02 \mathrm{~h}^{-1}$ respectively).

Similar to the polymerisation of L-lactide, the experimental $M_{\mathrm{n}}$ of the poly-rac-lactides produced using 2, 3 and 6 with $[\mathrm{LA}]_{0} /[\mathrm{M}]_{0}$ of 200 show good agreement with the calculated values, suggesting that all the metal centres of were active during polymerisation; $M_{\mathrm{n}}$ (calcd) of $27607 \mathrm{~g} \mathrm{~mol}^{-1}$ and $M_{\mathrm{n}}$ (GPC) of $26747 \mathrm{~g} \mathrm{~mol}^{-1}$ for 6 (Table 3). The experimental $M_{\mathrm{n}}$ of the poly-rac-lactides produced using 6 with $[\mathrm{LA}]_{0} /[\mathrm{M}]_{0}$ of 50 and 25 are also in good agreement with the calculated values. However, similar to the polymerisation of L-lactide, poly-raclactides produced using 3 with $[\mathrm{LA}]_{0} /[\mathrm{M}]_{0}$ of 50 and 25 show experimental $M_{\mathrm{n}}$ approximately 2 and 0.25 times larger than the calculated values respectively, suggesting that not all of the metal sites were active during polymerisation at these concentrations. $M_{\mathrm{w}} / M_{\mathrm{n}}$ for the polymers produced using 2 and 3 with $\left[[\mathrm{LA}]_{0} /[\mathrm{M}]_{0}\right.$ of 200 are relatively narrow, indicating controlled polymerisation $\left(M_{\mathrm{w}} / M_{\mathrm{n}}=1.23\right.$ and 1.14 respectively). However, $M_{\mathrm{w}} / M_{\mathrm{n}}$ for the polymers produced under all other conditions are relatively large, indicating that transesterification processes may be occurring $\left(M_{\mathrm{w}} / M_{\mathrm{n}}=1.38-1.57\right)$.

The homonuclear decoupled ${ }^{1} \mathrm{H}$ NMR spectra of the polyrac-lactides produced using 2 and 6 show the production of moderately heterotactic enriched PLA $\left(P_{\mathrm{r}}=0.66\right.$ and 0.69 respectively, where $P_{\mathrm{r}}$ is the probability of forming racemic linkages (Fig. S38 and S40†). Hence, we can expect that the polymerisation occurs by a chain-end mechanism. This indicates some degree of sterocontrol provided by the ligand environment, which is in contrast to $\mathrm{Pn}^{*}(\mathrm{H}) \mathrm{OR}$ systems where atactic PLA was formed. ${ }^{56}$ However, the homonuclear decoupled ${ }^{1} \mathrm{H}$ NMR spectrum of the poly-rac-lactide produced using 3 shows the production of atactic PLA $\left(P_{\mathrm{r}}=0.54\right)$ and indicates a lack of stereocontrol for this catalyst system (Fig. S39†). The MALDI-TOF mass spectrum for the poly-rac-lactides produced using 3 shows peak envelopes $\Delta m / z=144$ apart, demonstrating controlled polymerisation with no transesterification; as indicated by the narrow dispersity mentioned previously (Fig. S41†). The spectrum also reveals polymer chains consisting of polylactic acid repeat units with -O-2,6- ${ }^{i} \mathrm{Pr}-\mathrm{C}_{6} \mathrm{H}_{3}$ and $-\mathrm{OH}$ end groups, demonstrating lactide monomer insertion into the aryloxide bond and suggesting a coordination-insertion polymerisation mechanism where the aryloxide group initiates polymerisation. The MALDI-TOF mass spectrum for the poly-rac-lactides produced using 6 shows peak envelopes $\Delta m / z=72$ apart, indicative of intermolecular transesterification and highlighting that polymerisation using $\mathbf{6}$ is less controlled than 3 (Fig. S42†). This lesser degree of control is consistent with the larger $M_{\mathrm{w}} / M_{\mathrm{n}}$ recorded for 6 when compared to $3\left(M_{\mathrm{w}} / M_{\mathrm{n}}\right.$ of 1.38 and 1.14 respectively). Similar to polymerisation using 3, the MALDI-TOF mass spectrum of 6 reveals polymer chains consisting of polylactic acid repeat units with -O-2,6- ${ }^{t} \mathrm{Bu}-4-\mathrm{Me}-\mathrm{C}_{6} \mathrm{H}_{2}$ and $-\mathrm{OH}$ end groups.

A study to investigate the effects of solvent on polymerisation rate was conducted for the ROP of rac-lactide using 3 and 6 at $80{ }^{\circ} \mathrm{C}$ with $[\mathrm{LA}]_{0} /[\mathrm{M}]_{0}$ of 200 and $[\mathrm{LA}]_{0}$ of $2.0 \mathrm{M}$ (Fig. S30 and $\mathrm{S} 31$ and Table $S 4 \dagger$ ). For 3 , the rates of polymerisation in benzene- $d_{6}$ and chloroform- $d_{1}$ were similar $\left(k_{\text {obs }}\right.$ of 0.12 and $0.13 \mathrm{~h}^{-1}$ respectively). However, for 6 , polymerisation in benzene- $d_{6}$ was much faster than in chloroform- $d_{1}(0.11$ and $0.01 \mathrm{~h}^{-1}$ respectively). For both catalysts, tetrahydrofuran- $d_{8}$ was found to inhibit polymerisation, as was also observed for the ROP of L-lactide using an unsymmetrical permethylindenyl zirconocene, ${ }^{43}$ and is attributed to coordination of the tetrahydrofuran- $d_{8}$ molecules to the metal centres inhibiting the coordination of lactide monomers. The experimental $M_{\mathrm{n}}$ of the poly-rac-lactides produced using 3 and 6 in chloroform- $d_{1}$ are lower than the calculated values $\left(26988\right.$ and $9930 \mathrm{~g} \mathrm{~mol}^{-1}$ respectively for 3 and 6851 and $4337 \mathrm{~g} \mathrm{~mol}^{-1}$ respectively) with broad $M_{\mathrm{w}} / M_{\mathrm{n}}$ (1.86 for 6 ), which suggests a greater degree of transesterification reactions occur in chloroform- $d_{1}$ than in benzene- $d_{6}$.

The temperature of polymerisation was varied for the ROP of L-lactide using 2 and 3, and for the ROP of rac-lactide using 3 with $[\mathrm{LA}]_{0} /[\mathrm{M}]_{0}$ of 50 and $[\mathrm{LA}]_{0}$ of $0.5 \mathrm{M}$ (Fig. S32-S34 and Tables $\mathrm{S} 3$ and $\mathrm{S} 4 \dagger)$. As expected, the rate of polymerisation increased with an increase in polymerisation temperature as the system had more energy to overcome the activation barriers for polymerisation; $k_{\mathrm{obs}}$ of 0.30 and $0.79 \mathrm{~h}^{-1}$ at 80 and $100{ }^{\circ} \mathrm{C}$ respectively for the ROP of L-lactide using $2, k_{\mathrm{obs}}$ of $0.22,0.30$ and $0.35 \mathrm{~h}^{-1}$ at 60,70 and $80{ }^{\circ} \mathrm{C}$ respectively for the ROP of L-lactide using 3 , and $k_{\text {obs }}$ of $0.15,0.16$ and $0.18 \mathrm{~h}^{-1}$ at 60,70 and $80^{\circ} \mathrm{C}$ respectively for the ROP of rac-lactide using 3 . Akin to polymerisation at $80{ }^{\circ} \mathrm{C}$, the experimental $M_{\mathrm{n}}$ are approximately triple and double the calculated $M_{\mathrm{n}}$ for the polymerisation of $\mathrm{L}^{-}$and $\mathrm{rac}$-lactide respectively at 60 and $70{ }^{\circ} \mathrm{C} . M_{\mathrm{n}}$ and $M_{\mathrm{w}} / M_{\mathrm{n}}$ were also observed to increase with an increase in polymerisation temperature, indicating less controlled polymerisation and an increase in transesterification processes with an increase in temperature; $M_{\mathrm{n}}$ of 7999, 9800 and $9930 \mathrm{~g}$ $\mathrm{mol}^{-1}$ and $M_{\mathrm{w}} / M_{\mathrm{n}}$ of $1.27,1.51$ and 1.57 for the polymerisation of rac-lactide using 3 at 60,70 and $80^{\circ} \mathrm{C}$ respectively.

By varying the temperature of polymerisation of $\mathrm{L}^{-}$and $\mathrm{rac}^{-}$ lactide using 3 , the enthalpy $\left(\Delta H^{\ddagger}\right)$ and entropy $\left(\Delta S^{\ddagger}\right)$ of activation were calculated from an Eyring plot of $\ln \left(k_{\mathrm{obs}} / T\right) v s$. $(1 / T)$ (Fig. 7). For the polymerisation of L-lactide, $\Delta H^{*}=19 \mathrm{~kJ}$ $\mathrm{mol}^{-1}$ and $\Delta S^{\ddagger}=-270 \mathrm{~J} \mathrm{~mol}^{-1} \mathrm{~K}^{-1}$, and for the polymerisation of rac-lactide $\Delta H^{*}=6 \mathrm{~kJ} \mathrm{~mol}^{-1}$ and $\Delta S^{\star}=-312 \mathrm{~J} \mathrm{~mol}^{-1} \mathrm{~K}^{-1}$. $\Delta H^{\ddagger}$ are slightly lower than those reported for the ROP of 
$\mathrm{L}^{-}$and rac-lactide using $\mathrm{Pn}^{*}(\mathrm{H}) \mathrm{Zr}(\mathrm{OR})_{3}$ under similar conditions $\left(30<\Delta H^{\ddagger}<76 \mathrm{~kJ} \mathrm{~mol}^{-1}\right)$, with much less favourable $\Delta S^{\ddagger}\left(411<\Delta S^{\ddagger}<1847 \mathrm{~J} \mathrm{~K}^{-1} \mathrm{~mol}^{-1}\right) .{ }^{56}$ The $\Delta S^{\ddagger}$ values are more similar to those observed when using catalysts based on the permethylindenyl ligand $\left(\mathrm{C}_{9} \mathrm{Me}_{6}, \mathrm{I}^{*}\right) ;-155<\Delta S^{\ddagger}<-40 \mathrm{~J} \mathrm{~mol}^{-1}$ $\mathrm{K}^{-1}$ for the ROP of $\mathrm{L}^{-}$and rac-lactide using ${ }^{\mathrm{Me} 2} \mathrm{SB}\left(\mathrm{Cp}^{\mathrm{R}}, \mathrm{I}^{*}\right) \mathrm{ZrCl}_{2}$

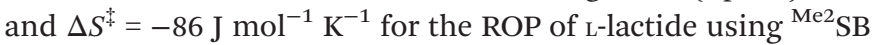

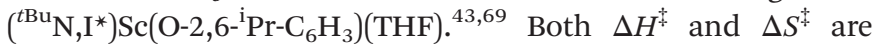
similar to, although albeit lower than, the values reported for the ROP of rac-lactide using a chiral alkoxy-bridged dinuclear indium catalyst $\left(\Delta H^{\ddagger}=49 \mathrm{~kJ} \mathrm{~mol}^{-1}\right.$ and $\Delta S^{\ddagger}=-140 \mathrm{~J} \mathrm{~K}^{-1}$ $\left.\mathrm{mol}^{-1}\right) .^{70}$ The low enthalpy and negative entropy for the polymerisation of $\mathrm{L}^{-}$and $r a c$-lactide using 3 are indicative of a more ordered transition state in the coordination-insertion polymerisation mechanism. ${ }^{71}$

\section{Conclusions}

A new family of group 4 permethylpentalene $\left(\mathrm{Pn}^{*}\right)$ aryloxide and alkoxide complexes $\left(\mathrm{Pn}^{*} \mathrm{ML}_{2} ; \mathrm{Zr}\right.$, Ti) have been synthesised and structurally characterised. Seven complexes have been investigated as initiators for the ring-opening polymerisation (ROP) of $\mathrm{L}^{-}$and rac-lactide. The initiators displayed firstorder dependence on monomer concentration. In general, polymerisation followed the trend $\mathrm{Pn}^{*} \mathrm{Zr}(\mathrm{OAr})_{2}>\mathrm{Pn}^{*} \mathrm{ZrCp}(\mathrm{OR})$ $>\mathrm{Pn}^{*} \mathrm{ZrCp}(\mathrm{OAr})$, with $\mathrm{Pn} * \mathrm{Zr}\left(\mathrm{O}-2,6-{ }^{i} \mathrm{Pr}-\mathrm{C}_{6} \mathrm{H}_{3}\right)$ (3) showing the fastest rate of polymerisation of L-lactide $\left(k_{\mathrm{obs}}=0.35 \mathrm{~h}^{-1}\right)$ and $\mathrm{Pn}^{*} \mathrm{Zr}\left(\mathrm{O}-2,6-\mathrm{Me}-\mathrm{C}_{6} \mathrm{H}_{3}\right)$ (2) showing the fastest rate of polymerisation of rac-lactide $\left(k_{\mathrm{obs}}=0.21 \mathrm{~h}^{-1}\right)$.

Isotactic PLA was produced for the ROP of L-lactide (demonstrating no epimerisation had occurred) and moderately heterotactic enriched PLA $\left(P_{\mathrm{r}}=0.66\right.$ and 0.69 for $\mathrm{Pn}{ }^{*} \mathrm{Zr}(\mathrm{O}-2,6-\mathrm{Me}-$ $\left.\mathrm{C}_{6} \mathrm{H}_{3}\right)_{2}$ (2) and $\mathrm{Pn} * \mathrm{ZrCl}\left(\mathrm{O}-2,6-{ }^{t} \mathrm{Bu}-4-\mathrm{Me}-\mathrm{C}_{6} \mathrm{H}_{2}\right)$ (6) respectively) or atactic PLA $\left(P_{\mathrm{r}}=0.54\right.$ for $\left.\mathrm{Pn} * \mathrm{Zr}\left(\mathrm{O}-2,6-{ }^{i} \mathrm{Pr}-\mathrm{C}_{6} \mathrm{H}_{3}\right)_{2}(3)\right)$ was produced for the ROP of rac-lactide, demonstrating that some degree of stereocontrol can be achieved with these initiators. In general, the molecular weights of the polylactides showed good agreement with the calculated values, suggesting that all metal centres were active during polymerisation. However, the molecular weight distributions were relatively large (maximum $M_{\mathrm{w}} / M_{\mathrm{n}}$ of 1.62), indicating that intermolecular transesterification processes may be occurring. Polymer chains consisting of polylactic acid repeat units with aryloxide and hydroxy end groups were identified, suggesting that polymerisation follows a coordination-insertion where the aryloxide group initiates polymerisation.

\section{Experimental}

\section{Synthesis of $\mathrm{Pn}^{*} \mathrm{Zr}\left(\mathrm{O}^{t} \mathrm{Bu}\right)_{2}(1)$}

1.0 equivalent $\left[\mathrm{Pn}^{*} \mathrm{ZrCl}_{2}\right] \cdot \mathrm{LiCl} \cdot(\mathrm{thf})_{1.85}(15.0 \mathrm{mg}, 0.017 \mathrm{mmol})$ and 4.0 equivalents $\mathrm{KO}^{t} \mathrm{Bu}(7.7 \mathrm{mg}, 0.069 \mathrm{mmol})$ were combined in benzene- $d_{6}(0.5 \mathrm{~mL})$ in a Young's tap NMR spectroscopy tube to give $\mathrm{Pn}^{*} \mathrm{Zr}\left(\mathrm{O}^{t} \mathrm{Bu}\right)_{2}(\mathbf{1})$ as a yellow solution. The instability of the complex prevented isolation on a preparative scale. ${ }^{1} \mathrm{H}$ NMR (benzene- $\left.d_{6}, 400 \mathrm{MHz}, 23{ }^{\circ} \mathrm{C}\right) \delta$ (ppm): 2.14 $\left(1,3,5,7-\mathrm{Me}^{-} \mathrm{Pn}^{*}, \quad 12 \mathrm{H}, \mathrm{s}\right), 1.91$ (2,6-Me-Pn*, 6H, s), 1.24 $\left(\mathrm{OCMe}_{3}, 18 \mathrm{H}, \mathrm{s}\right) \cdot{ }^{13} \mathrm{C}\left\{{ }^{1} \mathrm{H}\right\}$ NMR (benzene- $\left.d_{6}, 101 \mathrm{MHz}, 23{ }^{\circ} \mathrm{C}\right) \delta$ (ppm): 131.8 (2,6-Pn*), 130.5 (4,8-Pn*), 106.9 (1,3,5,7-Pn*), $74.4\left(\mathrm{OCMe}_{3}\right), 33.7\left(\mathrm{OCMe}_{3}\right), 12.6$ (1,3,5,7-Pn*), 11.2 (2,6-Pn*).

\section{Synthesis of $\mathrm{Pn} * \mathrm{Zr}\left(\mathrm{O}-2,6-\mathrm{Me}-\mathrm{C}_{6} \mathrm{H}_{3}\right)_{2}$ (2)}

1.0 equivalent $\left[\mathrm{Pn}^{*} \mathrm{ZrCl}_{2}\right]_{2} \cdot \mathrm{LiCl}(\mathrm{thf})_{x}(250 \mathrm{mg}, 0.285 \mathrm{mmol})$ and 4.0 equivalents $\mathrm{KO}-2,6-\mathrm{Me}-\mathrm{C}_{6} \mathrm{H}_{3}(247 \mathrm{mg}, 1.14 \mathrm{mmol}$ ) were combined in toluene $(10 \mathrm{~mL})$ in a Schlenk tube. The reaction was stirred for 24 hours at room temperature, filtered through Celite and dried in vacuo to yield $\mathrm{Pn} * \mathrm{Zr}\left(\mathrm{O}-2,6-\mathrm{Me}-\mathrm{C}_{6} \mathrm{H}_{3}\right)_{2}$ (2) as a yellow solid in $78 \%$ yield ( $282 \mathrm{mg}, 0.446 \mathrm{mmol}$ ). Crystals suitable for a single crystal X-ray diffraction study were grown from a hexane solution at $-30{ }^{\circ} \mathrm{C} .{ }^{1} \mathrm{H}$ NMR (benzene- $d_{6}, 400 \mathrm{MHz}$, $\left.23{ }^{\circ} \mathrm{C}\right) \delta(\mathrm{ppm}): 7.00\left(\mathrm{OArH}, 4 \mathrm{H}, \mathrm{d},{ }^{3} J_{\mathrm{H}-\mathrm{H}}=8 \mathrm{~Hz}\right), 6.75(\mathrm{OArH}$, $\left.2 \mathrm{H}, \mathrm{t},{ }^{3} \mathrm{~J}_{\mathrm{H}-\mathrm{H}}=8 \mathrm{~Hz}\right), 2.16$ (OArMe, 12H, s), 1.90 (2,6-Me-Pn*, 6H, s), 1.86 (1,3,5,7-Me-Pn*, 12H, s).

\section{Synthesis of $\operatorname{Pn}{ }^{*} \mathrm{Zr}\left(\mathrm{O}-2,6-{ }^{i}{ }^{\mathrm{Pr}}-\mathrm{C}_{6} \mathrm{H}_{3}\right)_{2}$ (3)}

1.0 equivalent $\left[\mathrm{Pn}^{*} \mathrm{ZrCl}_{2}\right]_{2} \cdot \mathrm{LiCl}(\mathrm{thf})_{1.85}(200 \mathrm{mg}, 0.229 \mathrm{mmol})$ and 4.0 equivalents $\mathrm{KO}-2,6{ }^{i}{ }^{i} \mathrm{Pr}-\mathrm{C}_{6} \mathrm{H}_{3}(198 \mathrm{mg}, 0.915 \mathrm{mmol})$ were combined in toluene $(5 \mathrm{~mL})$ in a Schlenk tube. The solution was sonicated for 10 minutes followed by stirring for $3 \mathrm{~h}$ at room temperature. The resulting pale yellow solution was dried in vacuo, the product extracted with hexane $(5 \mathrm{~mL})$ and concentrated to $\sim 2 \mathrm{~mL}$. Storage $-30{ }^{\circ} \mathrm{C}$ yielded $\mathrm{Pn}^{*} \mathrm{Zr}$ $\left(\mathrm{O}-2,6-{ }^{i}{ }^{\mathrm{Pr}}-\mathrm{C}_{6} \mathrm{H}_{3}\right)_{2}$ (3) as yellow crystals, suitable for a single crystal X-ray diffraction study, in $79 \%$ yield $(229 \mathrm{mg}$, $0.362 \mathrm{mmol}) .{ }^{1} \mathrm{H}$ NMR (benzene- $\left.d_{6}, 400 \mathrm{MHz}, 23{ }^{\circ} \mathrm{C}\right) \delta(\mathrm{ppm})$ : $7.05\left(\mathrm{ArH}, 4 \mathrm{H}, \mathrm{d},{ }^{3} \mathrm{~J}_{\mathrm{H}-\mathrm{H}}=8 \mathrm{~Hz}\right), 6.93\left(\mathrm{ArH}, 2 \mathrm{H}, \mathrm{t},{ }^{3} J_{\mathrm{H}-\mathrm{H}}=8 \mathrm{~Hz}\right)$, 3.20 (OArCHMe, $4 \mathrm{H}$, sept, ${ }^{3} J_{\mathrm{H}-\mathrm{H}}=8 \mathrm{~Hz}$ ), 1.95 (2,6-Me-Pn ${ }^{*}, 6 \mathrm{H}$, s), $1.88\left(1,3,5,7-M^{2}-P^{*}, 12 \mathrm{H}, \mathrm{s}\right), 1.24$ (OArCHMe, 24H, d, ${ }^{3} J_{\mathrm{H}-\mathrm{H}}$ $=8 \mathrm{~Hz}) \cdot{ }^{13} \mathrm{C}\left\{{ }^{1} \mathrm{H}\right\}$ NMR (benzene- $\left.d_{6}, 101 \mathrm{MHz}, 23{ }^{\circ} \mathrm{C}\right) \delta(\mathrm{ppm})$ : 156.2 (OAr), 136.4 (OAriPr), 133.4 (2,6-Pn*), 132.4 (4,8-Pn*), 123.2 (ArH), 120.0 (ArH), 110.4 (1,3,5,7-Pn*), 27.3 (OArCH), 24.2 (OArCHMe), 11.5 (1,3,5,7-Me-Pn*), 11.1 (2,6-Me-Pn*).

\section{Synthesis of $\mathrm{Pn}^{*} \mathrm{Zr}\left(\mathrm{O}-4-\mathrm{OMe}-\mathrm{C}_{6} \mathrm{H}_{4}\right)_{2}$ (4)}

1.0 equivalent $\left[\mathrm{Pn}^{*} \mathrm{ZrCl}_{2}\right]_{2} \cdot \mathrm{LiCl}(\mathrm{thf})_{1.85}(15.0 \mathrm{mg}, 0.017 \mathrm{mmol})$ and 4.0 equivalents $\mathrm{KO}-4-\mathrm{OMe}_{6} \mathrm{C}_{6} \mathrm{H}_{4}(11.1 \mathrm{mg}, 0.069 \mathrm{mmol})$ were combined in benzene- $d_{6}(0.5 \mathrm{~mL})$ in a Young's tap NMR spectroscopy tube to give a cloudy orange solution. Dimeric $\left[\mathrm{Pn} * \mathrm{Zr}\left(\mathrm{O}-4-\mathrm{OMe}-\mathrm{C}_{6} \mathrm{H}_{4}\right)_{2}\right]_{2}\left(4^{\prime}\right)$ was observed after $20 \mathrm{~h}$ at room temperature and dark orange crystals suitable for a single crystal $\mathrm{X}$-ray diffraction study were obtained from the benzene$d_{6}$ solution. $\left[\mathrm{Pn} * \mathrm{Zr}\left(\mathrm{O}-4-\mathrm{OMe}-\mathrm{C}_{6} \mathrm{H}_{4}\right)_{2}\right]_{2}\left(4^{\prime}\right)$ was dissolved in THF by sonication and heating at $65{ }^{\circ} \mathrm{C}$. Filtration and removal of solvent in vacuo afforded $\mathrm{Pn}{ }^{*} \mathrm{Zr}\left(\mathrm{O}-4-\mathrm{OMe}-\mathrm{C}_{6} \mathrm{H}_{4}\right)_{2}$ (4) as an orange solid. ${ }^{1} \mathrm{H}$ NMR (tetrahydrofuran- $d_{8}, 400 \mathrm{MHz}, 23{ }^{\circ} \mathrm{C}$ ) $\delta$ (ppm): 6.64 (OArH, 4H, d, $\left.{ }^{3} J_{\mathrm{H}-\mathrm{H}}=8 \mathrm{~Hz}\right), 6.50(\mathrm{OArH}, 4 \mathrm{H}, \mathrm{d}$, ${ }^{3} J_{\mathrm{H}-\mathrm{H}}=8 \mathrm{~Hz}$ ), 3.63 (OArOMe, 3H, s), 2.01 (2,6-Me-Pn*, 6H, s), 1.99 (1,3,5,7-Me-Pn*, $12 \mathrm{H}, \mathrm{s}) .{ }^{13} \mathrm{C}\left\{{ }^{1} \mathrm{H}\right\}$ NMR (tetrahydrofuran$\left.d_{8}, 101 \mathrm{MHz}, 23{ }^{\circ} \mathrm{C}\right) \quad \delta$ (ppm): 158.6 (OArOMe), 152.9 (OArOMe), $132.7\left(\mathbf{P n}^{*}\right), 128.9\left(\mathbf{P n}^{*}\right), 128.7\left(\mathbf{P n}^{*}\right), 128.4\left(\mathbf{P n}^{*}\right)$, 
119.7 (OArH), 115.2 (OArH), 107.6 (Pn*), 55.9 (OArOMe), 12.0 $\left(1,3,4,5-\mathbf{M e}^{-} \mathrm{Pn}^{*}\right), 11.4$ (2,6-Me-Pn*).

\section{Synthesis of $\mathrm{Pn}^{*} \mathrm{ZrCl}\left(\mathrm{O}-2,6^{-}{ }^{t} \mathrm{Bu}-\mathrm{C}_{6} \mathrm{H}_{3}\right)(5)$}

1.0 equivalent $\left[\mathrm{Pn}^{*} \mathrm{ZrCl}_{2}\right]_{2} \cdot \mathrm{LiCl}(\mathrm{thf})$ and 4.0 equivalents $\mathrm{KO}-2,6-{ }^{t} \mathrm{Bu}-\mathrm{C}_{6} \mathrm{H}_{3}$ were combined in benzene- $d_{6}(0.5 \mathrm{~mL})$ in a Young's tap NMR spectroscopy tube. $\mathrm{Pn} * \mathrm{ZrCl}\left(\mathrm{O}-2,6-{ }^{t} \mathrm{Bu}-\mathrm{C}_{6} \mathrm{H}_{3}\right)$ (5) was observed in seconds at room temperature in quantitative yield. Crystals of $\mathrm{Pn}{ }^{*} \mathrm{ZrCl}\left(\mathrm{O}-2,6-{ }^{t} \mathrm{Bu}-\mathrm{C}_{6} \mathrm{H}_{3}\right) \cdot \mathrm{LiCl}(\mathrm{tmeda})$ suitable for a single crystal $\mathrm{X}$-ray diffraction study were grown from a benzene solution of $\mathbf{5}$ at room temperature.

\section{Synthesis of $\mathrm{Pn} * \mathrm{ZrCl}\left(\mathrm{O}-2,{ }^{-}{ }^{t}{ }^{\mathrm{Bu}}-4-\mathrm{Me}-\mathrm{C}_{6} \mathrm{H}_{2}\right)(6)$}

1.0 equivalent $\left[\mathrm{Pn}^{*} \mathrm{ZrCl}_{2}\right]_{2} \cdot \operatorname{LiCl}(\mathrm{thf})_{x}(0.150 \mathrm{~g}, 0.171 \mathrm{mmol})$ and 4.0 equivalents $\mathrm{KO}-2,6-{ }^{t} \mathrm{Bu}-4-\mathrm{Me}-\mathrm{C}_{6} \mathrm{H}_{2}(0.089 \mathrm{~g}, 0.344 \mathrm{mmol})$ were combined in toluene $(3 \mathrm{~mL})$ in a gas-tight ampoule. The solution was stirred for $12 \mathrm{~h}$ at $70{ }^{\circ} \mathrm{C}$, and the resulting bright yellow solution dried in vacuo, extracted into toluene $(3 \times$ $30 \mathrm{~mL}$ ), filtered through a Celite and concentrated to approximately $1 \mathrm{~mL}$. Storage at $-30{ }^{\circ} \mathrm{C}$ yielded $\mathrm{Pn}{ }^{*} \mathrm{ZrCl}\left(\mathrm{O}-2,6-{ }^{t} \mathrm{Bu}-4-\right.$ Me- $\mathrm{C}_{6} \mathrm{H}_{2}$ ) (6) as large yellow crystals, suitable for a single crystal X-ray diffraction study, in $83 \%$ yield $(0.152 \mathrm{~g}$, $0.286 \mathrm{mmol}) .{ }^{1} \mathrm{H}$ NMR (benzene- $\left.d_{6}, 400 \mathrm{MHz}, 23{ }^{\circ} \mathrm{C}\right) \delta(\mathrm{ppm})$ : 7.19 (ArH, 2H, s), 2.34 (OArMe, 3H, s), 2.06 (1,3,5,7-Me-Pn*, 12H, s), 1.84 (2,6-Me-Pn*, 6H, s), $1.44\left(\mathrm{OArCMe}_{3}, 18 \mathrm{H}, \mathrm{s}\right) \cdot{ }^{13} \mathrm{C}$ $\left\{{ }^{1} \mathrm{H}\right\}$ NMR (benzene- $\left.d_{6}, 101 \mathrm{MHz}, 23{ }^{\circ} \mathrm{C}\right) \delta(\mathrm{ppm}): 159.6$ (OAr), $137.8\left(\mathrm{OArCMe}_{3}\right), 133.0\left(\mathrm{Pn}^{*}\right), 128.4\left(\mathrm{Pn}^{*}\right), 125.9(\mathrm{OArH}), 34.7$ $\left(\mathrm{OArCMe}_{3}\right), 31.9\left(\mathrm{OArCMe}_{3}\right), 21.5$ (OArMe), 12.2 (1,3,5,7-Me$\left.\mathrm{Pn}^{*}\right), 11.9$ (2,6-Me-Pn*); $2 \times$ quaternary carbons missing (Pn* and OArMe). CHN Analysis (\%): expected C 65.43, H 7.76, observed C 65.35, H 7.86.

\section{Synthesis of $\mathrm{Pn}^{*} \mathrm{ZrCp}\left(\mathrm{O}^{t} \mathrm{Bu}\right)(7)$}

1.0 equivalent $\mathrm{Pn}^{*} \mathrm{ZrCp}(\mathrm{Cl})(34.0 \mathrm{mg}, 0.0899 \mathrm{mmol})$ and 1.0 equivalent $\mathrm{KO}^{t} \mathrm{Bu}(10.1 \mathrm{mg}, 0.0899 \mathrm{mmol})$ were combined in benzene- $d_{6}(0.5 \mathrm{~mL})$ in a Young's tap NMR spectroscopy tube and sonicated at room temperature for 20 minutes to afford $\mathrm{Pn}{ }^{*} \mathrm{ZrCp}\left(\mathrm{O}^{t} \mathrm{Bu}\right)(7) .{ }^{1} \mathrm{H}$ NMR (benzene- $\left.d_{6}, 500 \mathrm{MHz}, 23{ }^{\circ} \mathrm{C}\right)$ : 5.82 (CpH, 5H, s), 2.05 (Pn*Me, 6H, s), 1.91 (Pn*Me, 6H, s), $1.89\left(\mathrm{Pn}^{*} \mathrm{Me}, 6 \mathrm{H}, \mathrm{s}\right), 1.19\left(\mathrm{OCMe}_{3}, 9 \mathrm{H}, \mathrm{s}\right) .{ }^{13} \mathrm{C}\left\{{ }^{1} \mathrm{H}\right\}$ NMR (benzene- $\left.d_{6}, 125 \mathrm{MHz}, 23{ }^{\circ} \mathrm{C}\right) \delta$ (ppm): 129.7 (Pn*), 127.4 $\left(\mathbf{P n}^{*}\right), 122.3\left(\mathbf{P n}^{*}\right), 109.7(\mathbf{C p}), 107.4\left(\mathbf{P n}^{*}\right), 102.5\left(\mathbf{P n}^{*}\right), 74.1$ $\left(\mathrm{OCMe}_{3}\right), 34.2\left(\mathrm{OCMe}_{3}\right), 13.4\left(\mathrm{Pn}^{*} \mathrm{Me}\right), 12.9\left(\mathrm{Pn}^{*} \mathrm{Me}\right), 11.6$ $\left(\mathrm{Pn}^{*} \mathrm{Me}\right)$.

\section{Synthesis of $\mathrm{Pn}^{*} \mathrm{ZrCp}\left(\mathrm{O}-2,6-\mathrm{Me}^{-} \mathrm{C}_{6} \mathrm{H}_{3}\right)(8)$}

1.0 equivalent $\mathrm{Pn}^{*} \mathrm{ZrCp}(\mathrm{Cl})(48.7 \mathrm{mg}, 0.129 \mathrm{mmol})$ and 1.0 equivalent $\mathrm{KO}-2,6-\mathrm{Me}-\mathrm{C}_{6} \mathrm{H}_{3}(25.2 \mathrm{mg}, 0.129 \mathrm{mmol})$ were combined in benzene- $d_{6}(0.5 \mathrm{~mL})$ in a Young's tap NMR spectroscopy tube and sonicated at room temperature until $\mathrm{KO}-2,6-$ Me- $\mathrm{C}_{6} \mathrm{H}_{3}$ fully dissolved, yielding $\mathrm{Pn}{ }^{*} \mathrm{ZrCp}\left(\mathrm{O}-2,6-\mathrm{Me}-\mathrm{C}_{6} \mathrm{H}_{3}\right)(8)$. ${ }^{1} \mathrm{H}$ NMR (benzene- $\left.d_{6}, 500 \mathrm{MHz}, 23{ }^{\circ} \mathrm{C}\right) \delta$ (ppm): 7.18 (OArH, $\left.2 \mathrm{H}, \mathrm{d},{ }^{3} \mathrm{~J}_{\mathrm{H}-\mathrm{H}}=10 \mathrm{~Hz}\right), 6.81\left(\mathrm{OArH}, 1 \mathrm{H}, \mathrm{t},{ }^{3} \mathrm{~J}_{\mathrm{H}-\mathrm{H}}=10 \mathrm{~Hz}\right), 5.50$ (CpH, 5H, s), 2.05 (OArMe, 3H, s), 1.90 (Pn*Me, 3H, s), 1.85 $\left(\mathrm{Pn}^{*} \mathrm{Me}, 3 \mathrm{H}, \mathrm{s}\right), 1.84(\mathrm{Pn} * \mathrm{Me}, 3 \mathrm{H}, \mathrm{s}) .{ }^{13} \mathrm{C}\left\{{ }^{1} \mathrm{H}\right\}$ NMR (benzene- $d_{6}$, $\left.125 \mathrm{MHz}, 23{ }^{\circ} \mathrm{C}\right) \delta$ (ppm): 165.1 (OAr), 130.7 (OArH), 128.7
$\left(\mathbf{P n}^{*}\right), 128.0\left(\mathbf{P n}^{*}\right)$ 127.0 $\left(\mathbf{P n}^{*}\right), 124.8$ (OArMe), 122.09, 116.5 (OArH), 110.7 (CpH), $110.3\left(\right.$ Pn $\left.^{*}\right), 102.9$ (Pn*), 17.2 (OArMe), $13.1\left(\mathrm{Pn}^{*} \mathrm{Me}\right), 11.5\left(\mathrm{Pn}^{*} \mathrm{Me}\right), 11.0\left(\mathrm{Pn}^{*} \mathrm{Me}\right)$.

\section{Synthesis of $\mathrm{Pn}^{*} \mathrm{ZrCp}\left(\mathrm{O}-2,6-{ }^{i} \mathrm{Pr}-\mathrm{C}_{6} \mathrm{H}_{3}\right)(9)$}

1.0 equivalent $\mathrm{Pn}^{*} \mathrm{ZrCp}(\mathrm{Cl})(50.9 \mathrm{mg}, 0.135 \mathrm{mmol})$ and 1.0 equivalent $\mathrm{KO}-2,6-{ }^{i} \mathrm{Pr}^{-} \mathrm{C}_{6} \mathrm{H}_{3}$ (29.1 mg, $0.135 \mathrm{mmol}$ ) were combined in benzene- $d_{6}(0.5 \mathrm{~mL})$ in a Young's tap NMR spectroscopy tube and sonicated at room temperature for 20 minutes to afford $\mathrm{Pn}{ }^{*} \mathrm{ZrCp}\left(\mathrm{O}-2,6-{ }^{i} \mathrm{Pr}^{-} \mathrm{C}_{6} \mathrm{H}_{3}\right)$ (9). ${ }^{1} \mathrm{H}$ NMR (benzene- $\left.d_{6}, 500 \mathrm{MHz}, 23{ }^{\circ} \mathrm{C}\right) \delta(\mathrm{ppm}): 7.17$ (OArH, 2H, d, $\left.{ }^{3} J_{\mathrm{H}-\mathrm{H}}=10 \mathrm{~Hz}\right), 6.97\left(\mathrm{OArH}, 1 \mathrm{H}, \mathrm{t},{ }^{3} \mathrm{~J}_{\mathrm{H}-\mathrm{H}}=10 \mathrm{~Hz}\right), 5.61(\mathrm{CpH}$, $5 \mathrm{H}, \mathrm{s}), 2.93\left(\mathrm{OArCHMe}_{2}, 2 \mathrm{H}\right.$, sept $\left.{ }^{3} J_{\mathrm{H}-\mathrm{H}}=10 \mathrm{~Hz}\right), 1.98\left(\mathrm{Pn}^{*} \mathbf{M e}\right.$, 3H, s), $1.89\left(\mathrm{Pn}^{*} \mathbf{M e}, 3 \mathrm{H}, \mathrm{s}\right), 1.87$ (Pn*Me, 3H, s), 1.33 $\left(\mathrm{OArCHMe}_{2}, 6 \mathrm{H}, \mathrm{d},{ }^{3} J_{\mathrm{H}-\mathrm{H}}=10 \mathrm{~Hz}\right), 1.21\left(\mathrm{OArCHMe}_{2}, 6 \mathrm{H}, \mathrm{d}\right.$, $\left.{ }^{3} J_{\mathrm{H}-\mathrm{H}}=10 \mathrm{~Hz}\right) \cdot{ }^{13} \mathrm{C}\left\{{ }^{1} \mathrm{H}\right\}$ NMR (benzene- $\left.d_{6}, 125 \mathrm{MHz}, 23{ }^{\circ} \mathrm{C}\right) \delta$ (ppm): 161.6 (OAr), 136.4 (OArCHMe $\left.{ }_{2}\right), 130.6\left(\mathbf{P n}^{*}\right), 127.3$ (Pn $\left.{ }^{*}\right), 123.8$ (ArH), 122.0 (Pn*), 117.8 (ArH), $111.1\left(\mathbf{P n}^{*}\right), 110.9$ $(\mathbf{C p H}), 103.7\left(\mathbf{P n}^{*}\right), 27.0\left(\mathrm{OArCHMe}_{2}\right), 25.7\left(\mathrm{OArCHMe}_{2}\right), 24.3$ (OArCHMe $\left.{ }_{2}\right), 13.7\left(\mathrm{Pn}^{*} \mathrm{Me}\right), 11.9\left(\mathrm{Pn}^{*} \mathrm{Me}\right), 11.2\left(\mathrm{Pn}^{*} \mathrm{Me}\right)$.

\section{Synthesis of Pn*TiCp(O-2,6-Me- $\left.\mathrm{C}_{6} \mathrm{H}_{3}\right)(10)$}

1.0 equivalent $\mathrm{Pn}^{*} \mathrm{TiCp}(\mathrm{Cl})(50 \mathrm{mg}, 0.15 \mathrm{mmol})$ and 1.2 equivalents $\mathrm{KO}-2,6-\mathrm{Me}-\mathrm{C}_{6} \mathrm{H}_{3}(29 \mathrm{mg}, 0.18 \mathrm{mmol})$ were combined in benzene- $d_{6}(0.5 \mathrm{~mL})$ in a Young's tap NMR spectroscopy tube. The solution was left for $24 \mathrm{~h}$ at room temperature, and was then filtered, dried in vacuo and the resulting dark orange solid extracted with pentane $(3 \times 10 \mathrm{~mL})$. Storage at $-80{ }^{\circ} \mathrm{C}$ yielded $\mathrm{Pn}^{*} \mathrm{TiCp}\left(\mathrm{O}-2,6-\mathrm{Me}-\mathrm{C}_{6} \mathrm{H}_{3}\right)(\mathbf{1 0})$ as a dark brown crystalline solid in $23 \%$ yield (15 mg, $0.04 \mathrm{mmol}$ ). ${ }^{1} \mathrm{H}$ NMR (benzene$\left.d_{6}, 500 \mathrm{MHz}, 23{ }^{\circ} \mathrm{C}\right) \delta(\mathrm{ppm}): 7.21\left(\mathrm{OArH}, 2 \mathrm{H}, \mathrm{d}, 3_{\mathrm{H}-\mathrm{H}}=10\right.$ $\mathrm{Hz}$ ), 6.85 (OArH, 1H, t, ${ }^{3} J=10 \mathrm{~Hz}$ ), 5.25 (CpH, 5H, s), 1.97 (OArMe, 6H, s), 1.97 (2,6-Me-Pn*, 6H, s), 1.70 (1,3,5,7-Me-Pn*, $12 \mathrm{H}, \mathrm{s}) .{ }^{13} \mathrm{C}\left\{{ }^{1} \mathrm{H}\right\}$ NMR (benzene- $\left.d_{6}, 125 \mathrm{MHz}, 23{ }^{\circ} \mathrm{C}\right) \delta(\mathrm{ppm})$ : 129.2 (OArH), $128.4\left(\right.$ Pn $\left.^{*}\right), 128.0$ (Pn*), 126.1 (OArMe), 124.7 (Pn $\left.{ }^{*}\right), 120.8\left(\right.$ Pn $\left.^{*}\right), 116.1$ (OArH), $112.1\left(\right.$ Pn $\left.^{*}\right), 110.8(\mathbf{C p H}), 17.8$ (OArMe), 13.9 (1,3,5,7-Me-Pn*), 13.0 (2,6-Me-Pn*), 11.2 (1,3,5,7Me-Pn*). $1 \times$ quaternary carbon missing (OAr).

\section{Synthesis of $\mathrm{Pn}^{*} \mathrm{ZrCp}^{\mathrm{Me}}\left(\mathrm{O}-2,6-\mathrm{Me}-\mathrm{C}_{6} \mathrm{H}_{3}\right)(11)$}

1.0 equivalent $\mathrm{Pn}^{*} \mathrm{ZrCp}^{\mathrm{Me}}(\mathrm{Cl})(18.0 \mathrm{mg}, 0.0459 \mathrm{mmol})$ and 1.0 equivalent $\mathrm{KO}-2,6-\mathrm{Me}-\mathrm{C}_{6} \mathrm{H}_{3}(8.96 \mathrm{mg}, 0.0459 \mathrm{mmol})$ were combined in benzene- $d_{6}(0.5 \mathrm{~mL})$ in a Young's tap NMR spectroscopy tube and sonicated for $2 \times 30$ minutes at room temperature to afford a yellow solution and colourless precipitate. After $16 \mathrm{~h}$ at room temperature, filtration followed by drying of the filtrate in vacuo afforded $\mathrm{Pn}^{*} \mathrm{ZrCp}^{\mathrm{Me}}\left(\mathrm{O}-2,6-\mathrm{Me}-\mathrm{C}_{6} \mathrm{H}_{3}\right)(\mathbf{1 1})$ as a pale yellow solid. Crystals, suitable for a single crystal X-ray diffraction study, grown from a pentane solution at $-30{ }^{\circ} \mathrm{C} .{ }^{1} \mathrm{H}$ NMR (benzene- $\left.d_{6}, 400 \mathrm{MHz}, 2{ }^{\circ} \mathrm{C}\right) \delta(\mathrm{ppm}): 7.17$ (OArH, 2H, $\left.\mathrm{d},{ }^{3} J_{\mathrm{H}-\mathrm{H}}=8 \mathrm{~Hz}\right), 6.82\left(\mathrm{OArH}, 1 \mathrm{H}, \mathrm{t},{ }^{3} J_{\mathrm{H}-\mathrm{H}}=8 \mathrm{~Hz}\right), 5.47(\mathrm{CpH}$, $2 \mathrm{H}$, app. t, $\left.{ }^{3} J_{\mathrm{H}-\mathrm{H}}=3 \mathrm{~Hz}\right), 5.20\left(\mathrm{CpH}, 2 \mathrm{H}\right.$, app. t, $\left.{ }^{3} J_{\mathrm{H}-\mathrm{H}}=3 \mathrm{~Hz}\right)$, 2.08 (OArMe, 6H, s), $1.92\left(\mathrm{Pn}^{*} \mathbf{M e}, 6 \mathrm{H}, \mathrm{s}\right), 1.88\left(\mathrm{Pn}^{*} \mathrm{Me}, 6 \mathrm{H}, \mathrm{s}\right)$, 1.84 (Pn*Me, 6H, s) 1.83 (CpMe, 3H, s). ${ }^{13} \mathrm{C}\left\{{ }^{1} \mathrm{H}\right\} \quad \mathrm{NMR}$ (benzene- $\left.d_{6}, 101 \mathrm{MHz}, 23{ }^{\circ} \mathrm{C}\right) \delta$ (ppm): 164.3 (OAr), 130.8 (Pn*), 129.0 (OArH), 127.4 (Pn*), 125.9 (OArMe), 123.7 (CpMe), 
$122.4\left(\mathbf{P n}^{*}\right), 116.7(\mathrm{OArH}), 111.0\left(\mathbf{P n}^{*}\right), 110.7(\mathbf{C p H}), 110.2$ $(\mathbf{C p H}), 102.7\left(\mathbf{P n}^{*}\right), 17.6$ (OArMe), 13.5 (CpMe), $13.4\left(\mathrm{Pn}^{*} \mathbf{M e}\right)$, $11.9\left(\mathrm{Pn}^{*} \mathrm{Me}\right), 10.8\left(\mathrm{Pn}^{*} \mathrm{Me}\right)$.

\section{Synthesis of $\mathrm{Pn}^{*} \mathrm{ZrCp}^{\mathrm{Me}}\left(\mathrm{O}-2,6-{ }^{i} \mathrm{Pr}-\mathrm{C}_{6} \mathrm{H}_{3}\right)(12)$}

1.0 equivalent $\mathrm{Pn}^{*} \mathrm{ZrCp}^{\mathrm{Me}}(\mathrm{Cl})(19.9 \mathrm{mg}, 0.0508 \mathrm{mmol})$ and 1.0 equivalent $\mathrm{KO}-2,6-{ }^{i} \mathrm{Pr}-\mathrm{C}_{6} \mathrm{H}_{3}(11.0 \mathrm{mg}, 0.0508 \mathrm{mmol})$ were combined in benzene- $d_{6}(0.5 \mathrm{~mL})$ in a Young's tap NMR spectroscopy tube and sonicated for $2 \times 30$ minutes at room temperature to afford a yellow solution and colourless precipitate. After $16 \mathrm{~h}$ at room temperature, filtration followed by drying of the filtrate in vacuo afforded $\mathrm{Pn}^{*} \mathrm{ZrCp}^{\mathrm{Me}}\left(\mathrm{O}-2,6-{ }^{i} \mathrm{Pr}^{-} \mathrm{C}_{6} \mathrm{H}_{3}\right)(\mathbf{1 2})$ as a pale yellow solid. ${ }^{1} \mathrm{H}$ NMR (benzene- $d_{6}, 400 \mathrm{MHz}, 23{ }^{\circ} \mathrm{C}$ ) $\delta$ (ppm): $7.17\left(\mathrm{OArH}, 2 \mathrm{H}, \mathrm{d},{ }^{3} J_{\mathrm{H}-\mathrm{H}}=8 \mathrm{~Hz}\right), 6.96(\mathrm{OArH}, 1 \mathrm{H}, \mathrm{t}$, $\left.{ }^{3} J_{\mathrm{H}-\mathrm{H}}=8 \mathrm{~Hz}\right), 5.64\left(\mathrm{CpH}, 2 \mathrm{H}\right.$, app. $\left.\mathrm{t},{ }^{3} J_{\mathrm{H}-\mathrm{H}}=3 \mathrm{~Hz}\right), 5.23(\mathrm{CpH}$, $2 \mathrm{H}$, app. $\left.\mathrm{t},{ }^{3} J_{\mathrm{H}-\mathrm{H}}=3 \mathrm{~Hz}\right), 2.93\left(\mathrm{OArCHMe}_{2}, 1 \mathrm{H}\right.$, sept., ${ }^{3} \mathrm{~J}_{\mathrm{H}-\mathrm{H}}=8$ Hz) 2.01 (Pn* Me, 6H, s), 1.90 (Pn*Me, 6H, s), 1.89 (СpMe, 3H, s), $1.87\left(\mathrm{Pn}^{*} \mathrm{Me}, 6 \mathrm{H}, \mathrm{s}\right), 1.35\left(\mathrm{OArCHMe}_{2}, 6 \mathrm{H}, \mathrm{d},{ }^{3} \mathrm{~J}_{\mathrm{H}-\mathrm{H}}=8 \mathrm{~Hz}\right)$, $1.21\left(\mathrm{OArCHMe}_{2}, 6 \mathrm{H}, \mathrm{d},{ }^{3} \mathrm{~J}_{\mathrm{H}-\mathrm{H}}=8 \mathrm{~Hz}\right.$ ). ${ }^{13} \mathrm{C}\left\{{ }^{1} \mathrm{H}\right\}$ NMR (benzene$\left.d_{6}, 101 \mathrm{MHz}, 23^{\circ} \mathrm{C}\right) \delta(\mathrm{ppm}): 160.7$ (OAr), $136.5\left(\mathrm{OArCHMe}_{2}\right)$, 130.3 (Pn*), 127.4 (Pn*), 123.9 (OArH), 123.8 (CpMe), 121.8 $\left(\mathbf{P n}^{*}\right), 117.7$ (OArH), $111.2\left(\mathbf{P n}^{*}\right), 110.5(\mathbf{C p H}), 109.5(\mathbf{C p H})$, 103.2 (Pn*), 27.4 (OArCHMe $\left.{ }_{2}\right), 25.7$ (OArCHMe $\left.{ }_{2}\right), \quad 24.5$ (OArCHMe ${ }_{2}$ ), 13.4 (Pn*Me), 13.4 (CpMe), 12.1 (Pn*Me), 10.7 $\left(\mathrm{Pn}^{*} \mathbf{M e}\right)$.

\section{Synthesis of $\mathrm{Pn}^{*} \mathrm{ZrCp}^{\mathrm{Me}}\left(\mathrm{O}-2,{ }^{-}{ }^{t} \mathrm{Bu}^{-} \mathrm{C}_{6} \mathrm{H}_{3}\right)(13)$}

1.0 equivalent $\mathrm{Pn}^{*} \mathrm{ZrCp}^{\mathrm{Me}}(\mathrm{Cl})(32.1 \mathrm{mg}, 0.0819 \mathrm{mmol})$ and 1.0 equivalent $\mathrm{KO}-2,4-{ }^{t} \mathrm{Bu}-\mathrm{C}_{6} \mathrm{H}_{3}(20.0 \mathrm{mg}, 0.0819 \mathrm{mmol})$ were combined in benzene- $d_{6}(0.5 \mathrm{~mL})$ in a Young's tap NMR spectroscopy tube and sonicated for $2 \times 30$ minutes at room temperature to afford a yellow solution and colourless precipitate. After $16 \mathrm{~h}$ at room temperature, filtration followed by drying of the filtrate in vacuo afforded $\mathrm{Pn}^{*} \mathrm{ZrCp}^{\mathrm{Me}}\left(\mathrm{O}-2,4{ }^{t}{ }^{\mathrm{Bu}}-\mathrm{C}_{6} \mathrm{H}_{3}\right)$ (13) as a pale yellow solid. ${ }^{1} \mathrm{H}$ NMR (benzene- $d_{6}, 400 \mathrm{MHz}, 23{ }^{\circ} \mathrm{C}$ ) $\delta$ (ppm): 7.57 (ArH, 1H, s), 7.27 (ArH, 1H, dd, $\left.{ }^{3} J_{\mathrm{H}-\mathrm{H}}=4,8 \mathrm{~Hz}\right)$, $5.99\left(\mathrm{ArH}, 1 \mathrm{H}, \mathrm{d},{ }^{3} J_{\mathrm{H}-\mathrm{H}}=8 \mathrm{~Hz}\right), 5.65(\mathrm{CpH}, 1 \mathrm{H}, \mathrm{m}), 5.57(\mathrm{CpH}$, 1H, m), 5.30 (CpH, 2H, m), $2.19\left(\mathrm{Pn}^{*} \mathbf{M e}, 3 \mathrm{H}, \mathrm{s}\right), 1.99\left(\mathrm{Pn}^{*} \mathbf{M e}\right.$, 3H, s), 1.93 (CpMe, 3H, s), 1.92 (Pn* Me, H, s), 1.90 (Pn*Me, 3H, s), 1.89 (Pn* Me, 3H, s), $1.85\left(\mathrm{Pn}^{*} \mathrm{Me}, 3 \mathrm{H}, \mathrm{s}\right), 1.60\left(\mathrm{ArCMe}_{3}\right.$, 9H, s), $1.42\left(\mathrm{ArCMe}_{3}, 9 \mathrm{H}, \mathrm{s}\right) .{ }^{13} \mathrm{C}\left\{{ }^{1} \mathrm{H}\right\}$ NMR (benzene- $d_{6}$, $\left.101 \mathrm{MHz}, 23{ }^{\circ} \mathrm{C}\right) \delta(\mathrm{ppm}): 163.2$ (OAr), $138.0\left(\mathrm{OArCMe}_{3}\right), 136.5$ $\left(\mathrm{OArCMe}_{3}\right), 127.30$ (Pn*), 126.83 (Pn*), 123.9 (ArH), 122.7 (ArH), 121.7 (ArH), 121.26 (Pn*), 121.21 (Pn*), 112.4 (CpMe), 112.2 (Pn*), $112.1\left(\mathbf{P n}^{*}\right), 111.6(\mathbf{C p H}), 109.7(\mathbf{C p H}), 108.8$ $(\mathbf{C p H}), \quad 104.4\left(\mathbf{P n}^{*}\right), \quad 103.3\left(\mathbf{P n}^{*}\right), \quad 35.7 \quad\left(\mathrm{OArCMe}_{3}\right), \quad 34.3$ $\left(\mathrm{OArCMe}_{3}\right), 32.3\left(\mathrm{OArCMe}_{3}\right), 31.5\left(\mathrm{OArCMe}_{3}\right), 13.7\left(\mathrm{Pn}^{*} \mathrm{Me}\right)$, 13.6 (Pn*Me), 13.5 (Pn* Me), 13.1 (Pn*Me), 11.9 (Pn* Me), 11.0 (CpMe), 10.8 (Pn*Me).

Lactide polymerisation procedure $\left([\mathrm{LA}]_{0} /[\mathrm{M}]_{0}=50,[\mathrm{LA}]_{0}=0.5 \mathrm{M}\right)$

50 equivalents $\mathrm{L}^{-}$or rac-lactide $(40 \mathrm{mg}, 0.278 \mathrm{mmol})$ were weighed into Young's tap NMR spectroscopy tubes and 1.0 equivalent initiator in benzene- $d_{6}(0.56 \mathrm{~mL})$, corresponding to an initial lactide concentration $\left([\mathrm{LA}]_{0}\right)$ of $0.5 \mathrm{M}$, added. Polymerisations were run at $60-100{ }^{\circ} \mathrm{C}$ and halted at certain time intervals by submerging the NMR tubes in an ice bath. Polymerisation was monitored by ${ }^{1} \mathrm{H}$ NMR spectroscopy. On completion, the reaction mixture was decanted into $-5{ }^{\circ} \mathrm{C}$ pentane $(10 \mathrm{~mL})$, the solution allowed to settle, and the solvent removed. The polymer was then washed with diethyl ether $(2 \times 10 \mathrm{~mL})$ and dried under vacuum at $30{ }^{\circ} \mathrm{C}$ for 18 hours.

Lactide polymerisation procedure $\left([\mathrm{LA}]_{0} /[\mathrm{M}]_{0}=200,[\mathrm{LA}]_{0}=2.0\right.$ M)

1.0 equivalent initiator (3 $\mathrm{mg}$ ) was dissolved in deuterated solvent $(0.5 \mathrm{~mL})$ and added to Young's tap NMR spectroscopy tubes. 200 equivalents $\mathrm{L}^{-}$or rac-lactide, corresponding to an initial lactide concentration ([LA $\left.]_{0}\right)$ of $2 \mathrm{M}$, was then added. Polymerisations were run between $80^{\circ} \mathrm{C}$ and halted at certain time intervals by submerging the NMR tubes in an ice bath. Polymerisation was monitored by ${ }^{1} \mathrm{H}$ NMR spectroscopy. On completion, the reaction mixture was decanted into $-5{ }^{\circ} \mathrm{C}$ pentane $(10 \mathrm{~mL})$, the solution allowed to settle, and the solvent removed. The polymer was then washed with diethyl ether $(2 \times 10 \mathrm{~mL})$ and dried under vacuum at $30{ }^{\circ} \mathrm{C}$ for 18 hours.

\section{Conflicts of interest}

There are no conflicts to declare.

\section{Acknowledgements}

Z.R.T., J.V.L., T.P.R., D.M. and J.-C.B. thank SCG Chemicals Co., Ltd (Thailand) for financial support and for a research Fellowship (Z.R.T). Chemical Crystallography (University of Oxford) is thanked for use of the diffractometers and Prof. Charlotte K. Williams (University of Oxford) is thanked for use of the GPC.

\section{Notes and references}

1 G. E. Luckachan and C. K. S. Pillai, J. Polym. Environ., 2011, 19, 637-676.

2 C. Romera-Castillo, M. Pinto, T. M. Langer, X. A. AlvarezSalgado and G. J. Herndl, Nat. Commun., 2018, 9, 7.

3 P. A. Gunatillake and R. Adhikari, Eur. Cells Mater., 2003, 5, 1-16.

4 P. J. Dijkstra, H. Z. Du and J. Feijen, Polym. Chem., 2011, 2, 520-527.

5 M. J. Stanford and A. P. Dove, Chem. Soc. Rev., 2010, 39, 486-494.

6 X. Zhang, M. Fevre, G. O. Jones and R. M. Waymouth, Chem. Rev., 2018, 118, 839-885.

7 Y. Zhu, C. Romain and C. K. Williams, Nature, 2016, 540, 354-362.

8 A. Sauer, A. Kapelski, C. Fliedel, S. Dagorne, M. Kol and J. Okuda, Dalton Trans., 2013, 42, 9007-9023. 
9 V. Nagarajan, A. K. Mohanty and M. Misra, ACS Sustainable Chem. Eng., 2016, 4, 2899-2916.

10 H. R. Kricheldorf, Chemosphere, 2001, 43, 49-54.

11 R. E. Drumright, P. R. Gruber and D. E. Henton, Adv. Mater., 2000, 12, 1841-1846.

12 R. Dattatray Karande, V. K. Abitha, A. Vasudeo Rane and R. K. Mishra, J. Mater. Sci. Eng. Adv. Tech., 2015, 12, 1-37.

13 R. W. F. Kerr, P. M. D. A. Ewing, S. K. Raman, A. D. Smith, C. K. Williams and P. L. Arnold, ACS Catal., 2021, 11, 15631569.

14 R. H. Platel, L. M. Hodgson and C. K. Williams, Polym. Rev., 2008, 48, 11-63.

15 B. J. O'Keefe, M. A. Hillmyer and W. B. Tolman, J. Chem. Soc., Dalton Trans., 2001, 2215-2224.

16 O. Dechy-Cabaret, B. Martin-Vaca and D. Bourissou, Chem. Rev., 2004, 104, 6147-6176.

17 P. J. Dijkstra, H. Du and J. Feijen, Polym. Chem., 2011, 2, 520-527.

18 D. C. Aluthge, B. O. Patrick and P. Mehrkhodavandi, Chem. Commun., 2013, 49, 4295-4297.

19 M. Normand, E. Kirillov, T. Roisnel and J. F. Carpentier, Organometallics, 2012, 31, 1448-1457.

20 D. Myers, A. J. P. White, C. M. Forsyth, M. Bown and C. K. Williams, Angew. Chem., Int. Ed., 2017, 56, 5277-5282.

21 S. Praban, P. Piromjitpong, V. Balasanthiran, S. Jayaraj, M. H. Chisholm, J. Tantirungrotechai and K. Phomphrai, Dalton Trans., 2019, 48, 3223-3230.

22 C. Bakewell, A. J. P. White, N. J. Long and C. K. Williams, Inorg. Chem., 2015, 54, 2204-2212.

23 C. Bakewell, T. P. A. Cao, N. Long, X. F. Le Goff, A. Auffrant and C. K. Williams, J. Am. Chem. Soc., 2012, 134, 2057720580.

24 C. Bakewell, T. P. A. Cao, X. F. Le Goff, N. J. Long, A. Auffrant and C. K. Williams, Organometallics, 2013, 32, 1475-1483.

25 E. Grunova, E. Kirillov, T. Roisnel and J. F. Carpentier, Organometallics, 2008, 27, 5691-5698.

26 A. Alaaeddine, C. M. Thomas, T. Roisnel and J. F. Carpentier, Organometallics, 2009, 28, 1469-1475.

27 W. K. Gu, P. F. Xu, Y. R. Wang, Y. M. Yao, D. Yuan and Q. Shen, Organometallics, 2015, 34, 2907-2916.

28 C. Bakewell, A. J. P. White, N. J. Long and C. K. Williams, Angew. Chem., Int. Ed., 2014, 53, 9226-9230.

29 Y. F. Yu, D. Yuan, Y. R. Wang and Y. M. Yao, J. Organomet. Chem., 2016, 819, 37-45.

30 Y. Liang, R. L. Duan, C. Y. Hu, L. L. Li, X. Pang, W. X. Zhang and X. S. Chen, Chin. J. Polym. Sci., 2018, 36, 185-189.

31 M. Wisniewski, A. L. Borgne and N. Spassky, Macromol. Chem. Phys., 1997, 198, 1227-1238.

32 N. Spassky, M. Wisniewski, C. Pluta and A. Le Borgne, Macromol. Rapid Commun., 1996, 197, 2627-2637.

33 C. P. Radano, G. L. Baker and M. R. Smith, J. Am. Chem. Soc., 2000, 122, 1552-1553.

34 Z. Zhong, P. J. Dijkstra and J. Feijen, Angew. Chem., Int. Ed., 2002, 41, 4510-4513.
35 Z. Zhong, P. J. Dijkstra and J. Feijen, J. Am. Chem. Soc., 2003, 125, 11291-11298.

36 M. H. Chisholm, J. C. Gallucci, K. T. Quisenberry and Z. Zhou, Inorg. Chem., 2008, 47, 2613-2624.

37 N. Nomura, R. Ishii, M. Akakura and K. Aoi, J. Am. Chem. Soc., 2002, 124, 5938-5939.

38 P. Hormnirun, E. L. Marshall, V. C. Gibson, A. J. P. White and D. J. Williams, J. Am. Chem. Soc., 2004, 126, 2688-2689.

39 B. M. Chamberlain, M. Cheng, D. R. Moore, T. M. Ovitt, E. B. Lobkovsky and G. W. Coates, J. Am. Chem. Soc., 2001, 123, 3229-3238.

40 C. Romain, B. Heinrich, S. Bellemin-Laponnaz and S. Dagorne, Chem. Commun., 2012, 48, 2213-2215.

41 A. J. Chmura, M. G. Davidson, C. J. Frankis, M. D. Jones and M. D. Lunn, Chem. Commun., 2008, 1293-1295.

42 J.-C. Buffet, G. R. Harris, J. J. Coward, T. A. Q. Arnold, Z. R. Turner and D. O'Hare, J. Organomet. Chem., 2016, 801, 87-95.

43 J. V. Lamb, J. C. Abell, J. E. McLaren, J.-C. Buffet, Z. R. Turner and D. O'Hare, Mol. Catal., 2020, 484, 110735.

44 D. A. X. Fraser, Z. R. Turner, J.-C. Buffet and D. O'Hare, Organometallics, 2016, 35, 2664-2674.

45 F. M. Chadwick, R. T. Cooper and D. O'Hare, Organometallics, 2016, 35, 2092-2100.

46 R. T. Cooper, F. M. Chadwick, A. E. Ashley and D. O'Hare, Organometallics, 2013, 32, 2228-2233.

47 D. D. Clement, S. C. Binding, T. A. Q. Arnold, F. M. Chadwick, I. J. Casely, Z. R. Turner, J.-C. Buffet and D. O'Hare, Polyhedron, 2019, 157, 146-151.

48 A. V. Firth, J. C. Stewart, A. J. Hoskin and D. W. Douglas, J. Organomet. Chem., 1999, 591, 185-193.

49 P. Angpanitcharoen, J. V. Lamb, Z. R. Turner, J.-C. Buffet and D. O'Hare, Mol. Catal., 2020, 498, 111275.

50 F. Benetollo, G. Cavinato, L. Crosara, F. Milani, G. Rossetto, C. Scelza and P. Zanella, J. Organomet. Chem., 1998, 555, 177-185.

51 W. A. Howard, T. M. Trnka and G. Parkin, Inorg. Chem., 1995, 34, 5900-5909.

52 O. T. Summerscales and F. G. N. Cloke, Coord. Chem. Rev., 2006, 250, 1122-1140.

53 T. Repo, G. Jany, M. Salo, M. Polamo and M. Leskela, J. Organomet. Chem., 1997, 541, 363-366.

54 K. Jonas, P. Kolb, G. Kollbach, B. Gabor, R. Mynott, K. Angermund, O. Heinemann and C. Krüger, Angew. Chem., Int. Ed., 1997, 36, 1714-1718.

55 M. Save, M. Schappacher and A. Soum, Macromol. Chem. Phys., 2002, 203, 889-899.

56 Z. R. Turner, J.-C. Buffet and D. O'Hare, Organometallics, 2014, 33, 3891-3903.

57 A. Meduri, M. Mazzeo, M. Lamberti, C. Capacchione and S. Milione, Mol. Catal., 2019, 471, 54-59.

58 Y. Ning, Y. Zhang, A. Rodriguez-Delgado and E. Y. X. Chen, Organometallics, 2008, 27, 5632-5640.

59 J.-C. Buffet, G. R. Harris, J. J. Coward, T. A. Q. Arnold, Z. R. Turner and D. O'Hare, J. Organomet. Chem., 2016, 801, 87-95. 
60 T. P. A. Cao, A. Buchard, X. F. Le Goff, A. Auffrant and C. K. Williams, Inorg. Chem., 2012, 51, 2157-2169.

61 S. Gendler, S. Segal, I. Goldberg, Z. Goldschmidt and M. Kol, Inorg. Chem., 2006, 45, 4783-4790.

62 F. Marchetti, G. Pampaloni, C. Pinzino, F. Renili, T. Repo and S. Vuorinen, Dalton Trans., 2013, 42, 2792-2802.

63 E. L. Whitelaw, M. G. Davidson and M. D. Jones, Chem. Commun., 2011, 47, 10004-10006.

64 E. L. Whitelaw, M. D. Jones and M. F. Mahon, Inorg. Chem., 2010, 49, 7176-7181.

65 A. T. Normand, R. Malacea-Kabbara, R. Lapenta, A. Dajnak, P. Richard, H. Cattey, A. Bolley, A. Grassi, S. Milione, A. Auffrant, S. Dagorne and P. Le Gendre, Dalton Trans., 2020, 49, 6989-7004.
66 M. D. Jones, S. L. Hancock, P. McKeown, P. M. Schafer, A. Buchard, L. H. Thomas, M. F. Mahon and J. P. Lowe, Chem. Commun., 2014, 50, 1596715970.

67 A. Stopper, J. Okuda and M. Kol, Macromolecules, 2012, 45, 698-704.

68 A. Stopper, T. Rosen, V. Venditto, I. Goldberg and M. Kol, Chem. - Eur. J., 2017, 23, 11540-11548.

69 N. Diteepeng, J.-C. Buffet, Z. R. Turner and D. O'Hare, Dalton Trans., 2019, 48, 16099-16107.

70 A. F. Douglas, B. O. Patrick and P. Mehrkhodavandi, Angew. Chem., Int. Ed., 2008, 47, 2290-2293.

71 D. Mandal, D. Chakraborty, V. Ramkumar and D. K. Chand, RSC Adv. , 2016, 6, 21706-21718. 